University of South Florida

DIGITAL COMMONS

@ UNIVERSITY OF SOUTH FLORIDA
Digital Commons @ University of

South Florida

$2-1-2002$

\title{
National Transit Bus Accident Data Collection and Analyses
}

CUTR

Follow this and additional works at: https://digitalcommons.usf.edu/cutr_nctr

\section{Scholar Commons Citation}

CUTR, "National Transit Bus Accident Data Collection and Analyses" (2002). Research Reports. 205.

https://digitalcommons.usf.edu/cutr_nctr/205

This Technical Report is brought to you for free and open access by the National Center for Transit Research (NCTR) Archive (2000-2020) at Digital Commons @ University of South Florida. It has been accepted for inclusion in Research Reports by an authorized administrator of Digital Commons @ University of South Florida. For more information, please contact digitalcommons@usf.edu. 
National Transit Bus Accident Data Collection \& Analysis

February 2002

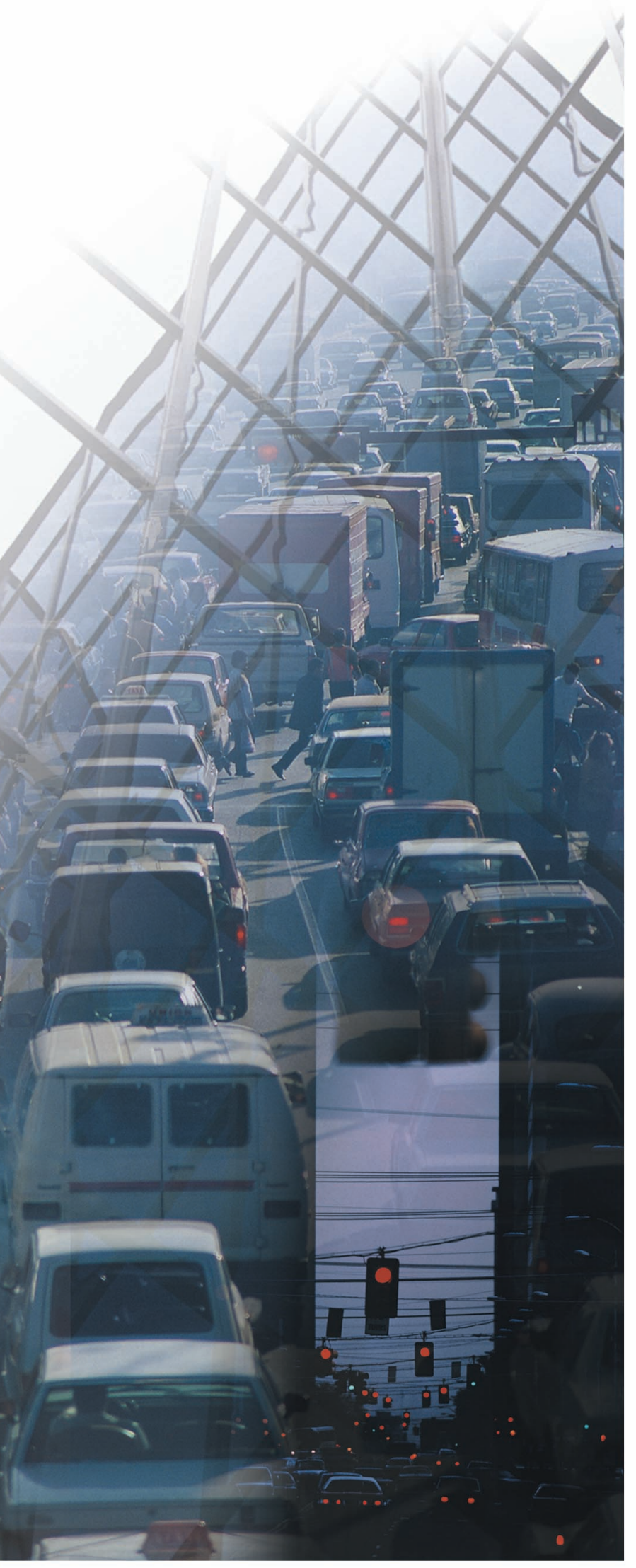




\begin{tabular}{|c|c|c|c|}
\hline $\begin{array}{l}\text { 1. Report No. } \\
\text { NCTR-416-13 }\end{array}$ & 2. Government Accession No. & \multicolumn{2}{|c|}{ 3. Recipient's Catalog No. } \\
\hline \multicolumn{2}{|c|}{$\begin{array}{l}\text { 4. Title and Subtitle } \\
\text { National Transit Bus Accident Data Collection and Analysis }\end{array}$} & \multicolumn{2}{|c|}{\begin{tabular}{l|} 
5. Report Date \\
February 2002
\end{tabular}} \\
\hline \multicolumn{2}{|c|}{$\begin{array}{l}\text { 7. Author(s) } \\
\text { Chandra Foreman, Joel R. Rey, Christopher DeAnnuntis }\end{array}$} & \multicolumn{2}{|c|}{\begin{tabular}{|l} 
8. Performing Organization Report No. \\
\end{tabular}} \\
\hline \multirow{2}{*}{\multicolumn{2}{|c|}{$\begin{array}{l}\text { 9. Performing Organization Name and Address } \\
\text { National Center for Transit Research (NCTR) } \\
\text { University of South Florida } \\
4202 \text { E. Fowler Ave., CUT100, Tampa, FL 33620-5375 }\end{array}$}} & \multicolumn{2}{|l|}{ 10. Work Unit No. } \\
\hline & & \multicolumn{2}{|c|}{$\begin{array}{l}\text { 11. Contract or Grant No. } \\
\text { DTRS98-G-0032 }\end{array}$} \\
\hline \multirow{2}{*}{\multicolumn{2}{|c|}{$\begin{array}{l}\text { 12. Sponsoring Agency Name and Address } \\
\text { Research \& Special Programs Admin., U.S. Department of Transportation, } \\
\text { RSPA/DIR-1, Room } 8417,4007^{\text {th }} \text { Street SW, Washington, D.C. } 20590 \\
\text { Florida Department of Transportation } \\
605 \text { Suwannee Street, MS 26, Tallahassee, FL } 32399-0450\end{array}$}} & \multirow{2}{*}{\multicolumn{2}{|c|}{\begin{tabular}{|l} 
13. Type of Report and Period Covered \\
\end{tabular}}} \\
\hline & & & \\
\hline \multicolumn{4}{|c|}{$\begin{array}{l}\text { 15. Supplementary Notes } \\
\text { Supported by a grant from the Florida Department of Transportation and the U.S. Department of Transportation. }\end{array}$} \\
\hline \multicolumn{4}{|c|}{$\begin{array}{l}\text { 16. Abstract } \\
\text { Through its National Center for Transit Research, and under contract with the Florida Department of Transportation } \\
\text { (FDOT), and in cooperation with the American Association of State Highway and Transportation Officials' Standing } \\
\text { Committee on Public Transportation (SCOPT) and the Multi-State Technical Assistance Program (MTAP), the Center } \\
\text { for Urban Transportation Research was tasked with reviewing the availability of data documenting public transit bus } \\
\text { collisions and incidents impacting public transit bus safety in the United States. Increasing publicity in recent years } \\
\text { about bus collisions has raised public awareness about the safety of travel on buses. FDOT, the SCOPT, and MTAP } \\
\text { are interested in the extent to which existing data sources can document the nature and scope of the problem across } \\
\text { the industry and provide focus to the development of national and local bus safety programs. }\end{array}$} \\
\hline $\begin{array}{l}\text { 17. Key Words } \\
\text { Transit, Accident/Incident, Safety, Bus } \\
\text { Crash, System Safety Plan }\end{array}$ & $\begin{array}{l}\text { 18. Distribution Statement } \\
\text { Available to the public through the } \\
\text { (NTIS), } 5285 \text { Port Royal Road, S } \\
\text { http://www.ntis.gov/. } \\
\text { An electronic version of this docu } \\
\text { format through the NCTR web sit }\end{array}$ & $\begin{array}{l}\text { lational Tech } \\
\text { igfield, VA } \\
\text { ent also is a } \\
\text { http://www. }\end{array}$ & $\begin{array}{l}\text { ormation Service } \\
3-605-6000 \text {, } \\
\text { the public in .pdf } \\
\text { edu/. }\end{array}$ \\
\hline $\begin{array}{l}\text { 19. Security Classif. (of this report) } \\
\text { Unclassified }\end{array}$ & $\begin{array}{l}\text { 20. Security Classif. (of this page) } \\
\text { Unclassified }\end{array}$ & $\begin{array}{l}\text { 21. No. of pages } \\
72\end{array}$ & 22. Price \\
\hline
\end{tabular}




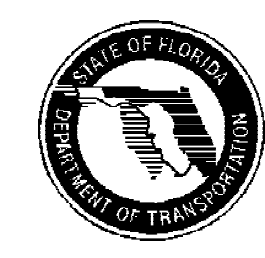

Prepared in cooperation with:

\section{State of Florida Department of Transportation \\ Public Transit Office \\ 605 Suwannee Street}

Tallahassee, FL 32399-0450

\section{Project Manager:}

James "Mike" Johnson

Administrator - Transit Operations

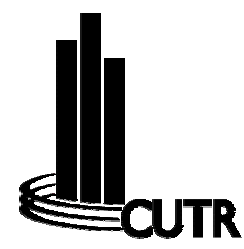

Prepared by:

\section{Center for Urban Transportation Research \\ University of South Florida \\ 4202 E. Fowler Avenue, CUT100 \\ Tampa, Florida 33620-5375}

(813) $974-3120$

Project Director:

Project Manager:

Project Staff:
Dennis Hinebaugh, Transit Program Director

Christopher DeAnnuntis, Research Associate

Chandra Foreman, Research Associate

Joel R. Rey, Sr. Research Associate

Anthony Chaumont, Undergraduate Student Assistant

The opinions, findings, and conclusions expressed in this publication are those of the authors and not necessarily those of the U.S. Department of Transportation or the State of Florida Department of Transportation. 


\section{Table of Contents}

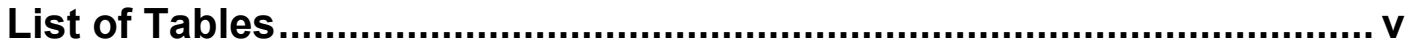

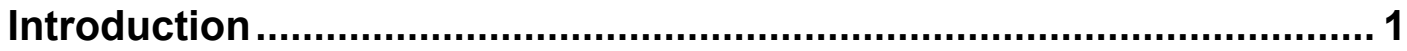

Analysis of State Databases .................................................................

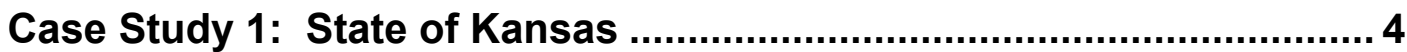

Bus Accident Involvement by Year........................................... 8

Bus Accident Involvement by Day of Week.................................. 9

Bus Accident Involvement by Time of Day .................................. 10

Bus Accident Involvement by Light Conditions............................... 12

Bus Accident Involvement by Weather Conditions ........................... 13

Bus Accident Involvement by On-Road Surface Condition ............... 14

Bus Accident Involvement by Type of Involvement ........................ 14

Bus Accident Involvement by Impact Dynamics ............................. 15

Summary of Kansas Case Study Findings ................................... 17

Case Study 2: State of Arizona .............................................................. 18

Bus Accident Involvement by Year.............................................. 23

Bus Accident Involvement by Time of Day ................................... 24

Bus Accident Involvement by Light Conditions............................... 25

Bus Accident Involvement by Weather Conditions ...........................26

Bus Accident Involvement by On-Road Surface Condition ................22

Bus Accident Involvement by Type of Involvement ......................... 28

Bus Accident Involvement by Impact Dynamics ............................... 29

Summary of Arizona Case Study Findings ..................................... 31

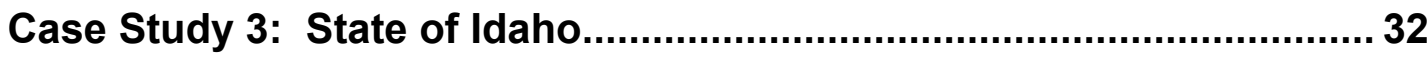

Bus Accident Involvement by Year............................................... 36

Bus Accident Involvement by Month ............................................. 37

Bus Accident Involvement by Day of Week.................................... 38

Bus Accident Involvement by Time of Day .................................... 38

Bus Accident Involvement by Light Conditions................................. 41

Bus Accident Involvement by Weather Conditions .......................... 41

Bus Accident Involvement by Road Surface Condition .................... 42

Bus Accident Involvement by Event Occurrence............................. 43

Type of Involvement .......................................................... 44

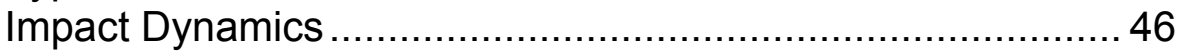

Summary of Idaho Case Study Findings .................................... 47

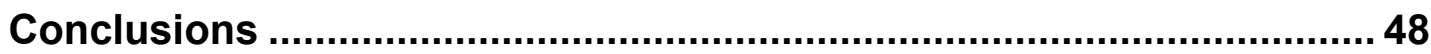

Uniformity in Accident Reporting Procedures ................................ 48

Uniformity in Records Collection and Database Maintenance........... 50

Appendix A 


\section{List of Tables}

\section{Case Study 1: State of Kansas}

Table 1. Comparison of State of Kansas Total Accidents Data and Database-Entered Data, 1991-2000.................................. 5

Table 2. Distributions for Accidents and Involved Vehicles by Year

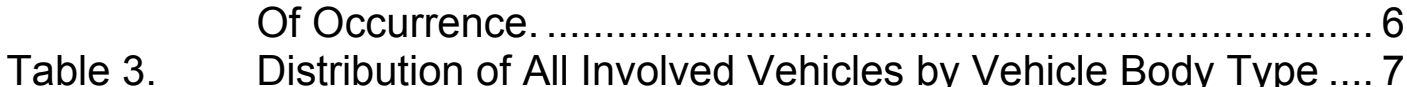

Table 4. Distributions for Involved Cross-Country and Transit Buses by Year. .......................................................... 9

Table 5. Distributions for Involved Cross-Country and Transit Buses By Day of Week............................................................ 10

Table 6. Distributions for Involved Cross-Country and Transit Buses By Time of Day.............................................................. 11

Table 7. Distributions for Involved Cross-Country and Transit Buses By Light Conditions..................................................... 12

Table 8. Distributions for Involved Cross-Country and Transit Buses By Weather Conditions...................................................... 13

Table 9. Distributions for Involved Cross-Country and Transit Buses By On-Road Surface Condition. .......................................... 14

Table 10. Distributions for Involved Cross-Country and Transit Buses By Type of Involvement. ............................................ 15

Table 11. Distributions for Involved Cross-Country and Transit Buses By Impact Dynamics ....................................................... 16

\section{Case Study 2: State of Arizona}

Table 12. Comparison of State of Arizona Total Accidents and Accidents Reported in Database by Year of Occurrence, 1991-2001..... 20

Table 13. Distributions for Accidents and Vehicles by Year of

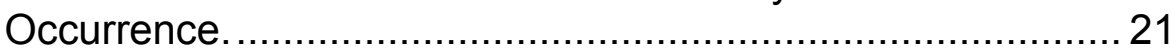

Table 14. Distribution of All Involved Vehicles by Vehicle Body Style. ... 22

Table 15. Distributions for Involved Commercial Buses By Year............ 24

Table 16. Distributions for Involved Commercial Buses By Time Of Day. ..................................................................... 25

Table 17. Distributions for Involved Commercial Buses by Light Conditions. ................................................................. 26

Table 18. Distributions for Involved Commercial Buses by Weather Conditions. ................................................................... 27

Table 19. Distributions for Involved Commercial Buses by On-Road Surface Conditions. ...................................................... 28

Table 20. Distributions for Involved Commercial Buses by Type of Involvement................................................................... 29

Table 21. Distributions for Involved Commercial Buses by Impact Dynamics 


\section{Case Study 3: State of Idaho}

Table 22. Comparison of State of Idaho Total Crash Data to Bus

Occurrence Data, 1996-2000.

Table 23. Distributions for Accidents and Involved Units by Year

Of Occurrence ....................................................................... 34

Table 24. Distribution of All Involved Units by Type. .............................35

Table 25. Distribution for Involved Buses by Year................................. 36

Table 26. Distribution for Involved Buses by Month. ..............................37

Table 27. Distributions for Involved Buses by Day of Week.................. 38

Table 28. Distributions for Involved Buses by Time of Day. ................... 40

Table 29. Distributions for Involved Buses by Light Condition................ 41

Table 30. Distributions for Involved Buses by Weather Conditions. ....... 42

Table 31. Distributions for Involved Buses by Road Surface Condition. ......................................................................... 43

Table 32. Distributions for Involved Buses by Type of Involvement. ...... 45

Table 33. Distributions for Involved Buses by Impact Dynamics. ............ 46

\section{Appendix A}

Table A-1. State and Individual Contact Information...............................55

Table A-2. North Dakota Yearly Totals Data Insert.................................66

Table A-3. South Dakota Yearly Totals Data Insert. ...............................6 66 


\section{NATIONAL TRANSIT BUS ACCIDENT \\ DATA COLLECTION AND ANALYSIS STUDY}

\section{INTRODUCTION}

The Center for Urban Transportation Research (CUTR), on behalf of the Florida Department of Transportation (FDOT), in cooperation with the American Association of State Highway and Transportation Officials' (AASHTO) Standing Committee on Public Transportation (SCOPT) and the Multi-State Technical Assistance Program (MTAP), is tasked with reviewing the availability of data documenting public transit bus collisions and incidents impacting public transit bus safety in the United States.

Increasing publicity in recent years about bus collisions has raised public awareness about the safety of travel on buses. FDOT, the SCOPT, and MTAP are interested in the extent to which existing data sources can document the nature and scope of the problem across the industry and provide focus to the development of national and local bus safety programs. Of particular interest is the comparison of public transit collisions and private carrier collisions, and collisions in the Section 5311 Rural Transportation and Section 5310 Elderly and Persons with Disabilities sectors of the industry.

The first task of the project involved data source identification and data collection. CUTR needed to collect public transit and private bus carrier accident data, using all available resources at both federal and state levels. Specifically, the goal was to collect accident data for each state. In addition to obtaining accident data, CUTR wanted to identify protocol for reporting and analyzing transit bus accident data. Cursory searches for data sources suggested that the most fruitful resources of information would be MTAP and various state Departments of Transportation (DOTs) or the equivalent and Departments of Public Safety (DPSs) throughout the country. 
The efforts to identify data sources first led CUTR to MTAP, which is an independent network of state transportation departments or agencies that exchange information and technical transit expertise between one another to efficiently solve technical transit problems. Through the MTAP website, http://www.mtap.org, hundreds of contacts from organizations representing transit interests (mainly DOTs) were identified. Consequently, CUTR began communications with the MTAP contacts mainly through electronic mail (email) to identify those who would be able to serve as data resources for their respective states. While email was the most efficient way to correspond with such a large number of contacts and the easiest way to maintain record of those communications, other methods of communication, such as postal mail-outs, phone calls, and facsimile were also utilized.

In an effort to obtain accident data and reporting protocol for those states that were not contacted through the MTAP search, CUTR also identified contacts through the USDOT website (http://www.dot.gov) or through websites for particular states. Upon exhausting all DOT contacts, the DPSs for the remaining states were contacted. Again, these sources were obtained directly off the Internet and communications were email-based.

Other resources included, but were not limited to, the Federal Transit Administration (FTA), the FTA National Transit Database, Federal Motor Carrier Safety Administration, National Safety Council, National Highway Transportation Safety Administration - Fatal Accident Reporting Systems, Association of Government Risk Pools, Risk and Insurance Management Society, and other state-level agencies such as Departments of Revenue, Accident Statistics Offices, Commissions on Aging, General Services Departments, Fire and Police Departments, as well as the Transportation Research Board. 
Given the multitude of resources identified through the organizations listed above, CUTR anticipated that acquiring the data from each state would yield moderate success. Instead, however, contact with the resources provided very little data and, overall, the data collection process was extremely disappointing and unsuccessful. In general, contacts seemed to be non-responsive which, after attempts at contact through email, telephone, and facsimile, suggested that they were either uninterested in participating or too busy to respond to requests for information despite CUTR's efforts to relay the importance of the study. Given the nature of the data being requested, some difficulty in gathering data was expected; however, the extent to which this proved to be true was unforeseen. As time elapsed and multiple attempts at contacting representatives from each state failed, the scope of the project was modified. After having accepted that data were not going to be available at the scale originally intended in the project scope, CUTR determined that the data collected could be illustrated through case studies to demonstrate what could be done if success at getting the data is achieved at a later time.

\section{ANALYSIS OF STATE DATABASES}

The data source identification and data collection process yielded results from three of the fifty states contacted. Representatives from the Departments of Transportation from Arizona and Kansas, as well as a representative from the Idaho Transportation Department, provided data regarding public transit bus accidents. These representatives also provided information about reporting protocols in the event of a commercial bus vehicle incident. Each of these states acknowledged maintaining an active database of commercial vehicles and having specific accident reporting protocols. As is evident through the case studies detailed in subsequent sections, the collection and reporting procedures of each state varies, which resulted in variation with regards to the format of the data received by CUTR. Consequently, different methods and software were utilized when extracting and analyzing each state's data. Those methods, as 
well as other pertinent information are described in the following three case study presentations.

\section{Case Study 1: State of Kansas}

According to the State of Kansas accident reporting criteria, an accident is defined as "an unstabilized situation that includes at least one harmful event." Officials determine an incident to be an accident based on several factors, including:

- the incident included loss in the format of damage or at least one injury;

- the incident involved unintentional injury or damage;

- the injury or damage was not a result of a cataclysm;

- the incident involved at least one motor vehicle in transportation;

- the incident was an unstabilized situation; and

- the unstabilized situation, injury, or damage originated or occurred on a traffic way.

Those accidents that involve either a fatality, injury, or property damage of at least $\$ 500$ are reported to the State. Accidents resulting only in property damage of less than $\$ 500$ are "non-reportable" and, therefore, are not entered into the State's automated database system and are not included in statewide accident data summaries.

Initially, CUTR requested assistance from the MTAP representative from the Kansas DOT. After having been assured that the data would be used as specified, Kansas DOT forwarded diskettes containing the accident records database. The database that Kansas DOT sent was originally developed using Microsoft Access. The accident records contained in the database span from year 1991 through 2000, and include a host of descriptive accident variables such as day of week, time of day, the type(s) of vehicle(s) involved, light 
conditions, weather conditions, roadway surface condition, type of involvement, and the related impact dynamics, among others. Due to the massive size of the database, Access had to be utilized to conduct the frequency and crosstabulation analyses that were performed on the data.

According to Kansas' State Highway Safety Office, Kansas had 717,265 total accidents from 1991 through 2000. Besides having a database that originated over 10 years ago, Kansas also has a rather thorough accident database. As shown in Table 1, all but two of the total accidents are included in the statewide accident database, which included 717,263 accidents. In addition, Table 1 shows that the number of accidents in Kansas steadily increased from 1991 to 1998, with the exception of a small decrease in 1994. However in every year since 1998, the number of accidents in the state has dropped.

Table 1

Comparison of State of Kansas Total Accidents Data and Database-Entered Data, 1991-2000

\begin{tabular}{|c|c|c|c|}
\hline Year & Total Accidents & $\begin{array}{c}\text { Accidents Entered in } \\
\text { Database }\end{array}$ & \% of Total Accidents \\
\hline 1991 & 61,920 & 61,920 & 100.0 \\
\hline 1992 & 63,964 & 63,964 & 100.0 \\
\hline 1993 & 69,641 & 69,641 & 100.0 \\
\hline 1994 & 66,835 & 66,835 & 100.0 \\
\hline 1995 & 70,263 & 70,263 & 100.0 \\
\hline 1996 & 73,872 & 73,872 & 100.0 \\
\hline 1997 & 76,642 & 76,642 & 100.0 \\
\hline 1998 & 79,114 & 79,112 & $100.0^{*}$ \\
\hline 1999 & 78,240 & 78,240 & 100.0 \\
\hline 2000 & 76,774 & 76,774 & 100.0 \\
\hline Total & 717,265 & 717,263 & $100.0^{*}$ \\
\hline
\end{tabular}

* Actual percentage equals 99.9997 
Table 2 presents the distributions for the database-reported accidents and involved vehicles by year of occurrence. In total, the database includes records for 717,263 accidents that involved a total of 924,268 vehicles from 1991 through 2000 , suggesting that the average accident during that period involved 1.29 vehicles.

Table 2

Distributions for Accidents and Involved Vehicles by Year of Occurrence

\begin{tabular}{|c|c|c|c|c|}
\hline Year & No. of Accidents & \% Distribution & No. of Vehicles & \% Distribution \\
\hline 1991 & 61,920 & 8.6 & 78,842 & 8.5 \\
\hline 1992 & 63,964 & 8.9 & 82,106 & 8.8 \\
\hline 1993 & 69,641 & 9.7 & 89,769 & 9.7 \\
\hline 1994 & 66,835 & 9.3 & 85,963 & 9.3 \\
\hline 1995 & 70,263 & 9.8 & 91,040 & 9.8 \\
\hline 1996 & 73,872 & 10.3 & 95,228 & 10.3 \\
\hline 1997 & 76,642 & 10.7 & 98,874 & 10.7 \\
\hline 1998 & 79,112 & 11.0 & 102,201 & 11.1 \\
\hline 1999 & 78,240 & 10.9 & 101,125 & 10.9 \\
\hline 2000 & 76,774 & 10.7 & 99,120 & 10.7 \\
\hline Total & 717,263 & 100.0 & 924,268 & 100.0 \\
\hline
\end{tabular}

In addition, one of the variables included in the database classified all of the vehicles by specific body type. The distribution of all involved vehicles by respective body type is displayed in Table 3 . This information was particularly useful in the analysis performed by CUTR, as accidents involving transit and commercial buses were the focus of the study. In the case of Kansas, commercial buses were identified as cross-country buses. 
Table 3

Distribution of All Involved Vehicles by Vehicle Body Type

\begin{tabular}{|l|c|c|}
\hline \multicolumn{1}{|c|}{ Code - Vehicle Body Type } & No. of Vehicles & \% Distribution \\
\hline 1 - Automobile & 556,790 & 60.2 \\
\hline 2 - Motorcycle & 7,317 & 0.8 \\
\hline 3 - Motor scooter or moped & 392 & 0.0 \\
\hline 4 - Van & 77,561 & 8.4 \\
\hline 5 - Pickup truck & 212,785 & 23.0 \\
\hline 6 - Single truck, 4 tires & 6,347 & 0.7 \\
\hline 7 - Camper or RV & 1,072 & 0.1 \\
\hline 8 - Farm equipment & 1,440 & 0.2 \\
\hline 9 - All-terrain vehicle & 285 & 0.0 \\
\hline 10 - Single truck over 4 tires & 14,166 & 1.5 \\
\hline 11 - Truck and trailer(s) & 4,203 & 0.5 \\
\hline 12 - Tractor-trailer(s) & 21,606 & 2.3 \\
\hline 13 - Cross-country bus & 51 & 0.0 \\
\hline 14 - School bus & 2,524 & 0.3 \\
\hline 15 - Transit bus & 768 & 0.0 \\
\hline 25 - Train & 489 & 0.0 \\
\hline 88 - Other & 3,908 & 0.4 \\
\hline 99 - n/a & 12,564 & 1.4 \\
\hline Total & 924,268 & 100.0 \\
\hline
\end{tabular}

Given the intent of the scope of this project, only accidents involving crosscountry buses (Body Type 13) and transit buses (Body Type 15) were included in subsequent analyses. As shown in Table 3, there were a total of 51 crosscountry buses and 768 transit buses involved in accidents during the 10-year time frame of the database. The following sections detail the findings from the bus-specific analyses for selected accident variables from the database. 


\section{Bus Accident Involvement by Year}

Table 4 illustrates the frequency distribution by year of transit buses and crosscountry buses involved in accidents. As the table shows, the number of crosscountry buses involved in accidents for the year 2000 is half the number it was in 1991. While the number of cross-county buses involved in accidents on Kansas roadways has fluctuated slightly, the only year in which the number of crosscountry buses involved in an accident was greater than seven was in 1993, when 12 cross-country buses were involved in accidents.

On the other hand, the number of transit buses involved in accidents is significantly greater than cross-country buses. This is expected as transit buses are involved in more maneuvering than cross-country buses and are exposed to more frequent contact with other vehicles than are cross-country buses, which operate mainly in highway environments. As Table 4 shows, the number of transit buses involved in accidents during the prescribed period has also fluctuated. However, the number of transit buses involved in accidents in 2000 was significantly greater than in 1991 . One possible reason for the sharp increase in the number of transit buses involved in accidents from 1991 to 2000 might be a corresponding increase in the number of transit vehicles in operation or in total transit service provided (in terms of vehicle miles). However, without knowing the number of transit vehicles in operation each year or the number of service miles provided, such analysis is not feasible. 
Table 4

Distributions for Involved Cross-Country and Transit Buses by Year

\begin{tabular}{|c|c|c|c|c|}
\hline Year & Cross-Country Buses & \% Distribution & Transit Buses & \% Distribution \\
\hline 1991 & 6 & 11.8 & 63 & 8.2 \\
\hline 1992 & 7 & 13.7 & 64 & 8.3 \\
\hline 1993 & 12 & 23.5 & 56 & 7.3 \\
\hline 1994 & 5 & 9.8 & 55 & 7.2 \\
\hline 1995 & 1 & 2.0 & 79 & 10.3 \\
\hline 1996 & 2 & 3.9 & 74 & 9.6 \\
\hline 1997 & 5 & 9.8 & 83 & 10.8 \\
\hline 1998 & 7 & 13.7 & 85 & 11.1 \\
\hline 1999 & 3 & 5.9 & 107 & 13.9 \\
\hline 2000 & 3 & 5.9 & 102 & 13.3 \\
\hline Total & 51 & 100.0 & 768 & 100.0 \\
\hline
\end{tabular}

Bus Accident Involvement by Day of Week

Table 5 shows the frequency distribution for the days of the week on which cross-country buses and transit buses were involved in accidents in 1991 through 2000. The day on which most cross-country buses were involved in accidents is Friday (23.5 percent), followed by Wednesday (17.6 percent) and Monday (15.7 percent). Tuesday and Thursday are the days on which the fewest number of cross-country buses are involved in accidents.

Most transit buses, as illustrated in Table 5, appear to have been involved in accidents on Tuesday than any other day of the week. The remaining weekdays have a consistent number of transit vehicles involved in accidents. The dramatic drop in the number of transit buses involved in accidents on Saturday and Sunday reflect the drop in the amount of transit service that typically is provided on weekend days in comparison to weekdays. 
Table 5

Distributions for Involved Cross-Country and Transit Buses by Day of Week

\begin{tabular}{|l|c|c|c|c|}
\hline Day of Week & Cross-Country Buses & \% Distribution & Transit Buses & \% Distribution \\
\hline Monday & 8 & 15.7 & 134 & 17.4 \\
\hline Tuesday & 5 & 9.8 & 160 & 20.8 \\
\hline Wednesday & 9 & 17.6 & 132 & 17.2 \\
\hline Thursday & 4 & 7.8 & 126 & 16.4 \\
\hline Friday & 12 & 23.5 & 135 & 17.6 \\
\hline Saturday & 6 & 11.8 & 59 & 7.7 \\
\hline Sunday & 7 & 13.7 & 22 & 2.9 \\
\hline Total & 51 & 100.0 & 768 & 100.0 \\
\hline
\end{tabular}

Bus Accident Involvement by Time of Day

Table 6 presents the frequency distribution for the various times of the day on which cross-country buses and transit buses were involved in accidents from 1991 through 2000. The time period during which the most cross-country buses were involved in accidents is 5:00-5:59 p.m. (17.6 percent). One-quarter of the total cross-country buses in question were involved in accidents between 4:005:59 p.m. (25.4 percent). This time period coincides with the actual afternoon peak period typically associated with most urbanized areas (i.e., 4:00-6:00 p.m.). Consequently, the cross-country buses may be exposed to increased amounts of traffic during this time, if they are traveling near or within urbanized areas.

As shown in Table 6, the time period during which the most transit buses were involved in accidents is 4:00-4:59 p.m. Other time periods in which relatively high numbers of transit buses were involved in accidents are 3:00-3:59 p.m. (10.3 percent), 8:00-8:59 a.m. (9.1 percent), and 7:00-7:59 a.m. (8.2 percent), which all fall within the more typical morning and afternoon peak period travel times (i.e. 6:00-9:00 a.m., 4:00-6:00 p.m.). 
Table 6

Distributions for Involved Cross-Country and Transit Buses by Time of Day

\begin{tabular}{|c|c|c|c|c|}
\hline Time of Day & $\begin{array}{c}\text { Cross-Country } \\
\text { Buses }\end{array}$ & $\%$ Distribution & Transit Buses & $\%$ Distribution \\
\hline 12 to $12: 59 \mathrm{AM}$ & 1 & 2.0 & 3 & 0.4 \\
\hline 1 to $1: 59$ AM & 1 & 2.0 & 2 & 0.3 \\
\hline 2 to $2: 59 \mathrm{AM}$ & 1 & 2.0 & 1 & 0.1 \\
\hline 3 to $3: 59 \mathrm{AM}$ & 0 & 0.0 & 2 & 0.3 \\
\hline 4 to $4: 59$ AM & 2 & 3.9 & 5 & 0.7 \\
\hline 5 to $5: 59 \mathrm{AM}$ & 3 & 5.9 & 5 & 0.7 \\
\hline 6 to $6: 59 \mathrm{AM}$ & 1 & 2.0 & 24 & 3.1 \\
\hline 7 to $7: 59$ AM & 4 & 7.8 & 63 & 8.2 \\
\hline 8 to $8: 59$ AM & 0 & 0.0 & 70 & 9.1 \\
\hline 9 to $9: 59$ AM & 3 & 5.9 & 57 & 7.4 \\
\hline 10 to $10: 59 \mathrm{AM}$ & 2 & 3.9 & 58 & 7.6 \\
\hline 11 to $11: 59$ AM & 1 & 2.0 & 53 & 6.9 \\
\hline 12 to $12: 59$ PM & 3 & 5.9 & 48 & 6.3 \\
\hline 1 to $1: 59$ PM & 1 & 2.0 & 53 & 6.9 \\
\hline 2 to $2: 59 \mathrm{PM}$ & 2 & 3.9 & 44 & 5.7 \\
\hline 3 to $3: 59$ PM & 4 & 7.8 & 79 & 10.3 \\
\hline 4 to $4: 59$ PM & 4 & 7.8 & 89 & 11.6 \\
\hline 5 to $5: 59$ PM & 9 & 17.6 & 57 & 7.4 \\
\hline 6 to $6: 59 \mathrm{PM}$ & 3 & 5.9 & 36 & 4.7 \\
\hline 7 to $7: 59$ PM & 1 & 2.0 & 6 & 0.8 \\
\hline 8 to $8: 59$ PM & 3 & 5.0 & 3 & 0.4 \\
\hline 9 to $9: 59$ PM & 1 & 2.0 & 5 & 0.7 \\
\hline 10 to $10: 59$ PM & 0 & 0.0 & 2 & 0.3 \\
\hline 11 to $11: 59$ PM & 1 & 2.0 & 2 & 0.3 \\
\hline$n / a$ & 0 & 0.0 & 1 & 0.1 \\
\hline Total & 51 & 100.0 & 768 & 100.0 \\
\hline
\end{tabular}




\section{Bus Accident Involvement by Light Conditions}

Table 7 shows the frequency distribution for various light conditions during which most cross-country buses and transit buses were involved in accidents from 1991 through 2000. The table presents the number of cross-country buses and transit buses involved in accidents for daylight, dawn, dusk, and dark (both with and without streetlights) conditions. For both cross-country and transit buses, the light condition at which most were involved in accidents is daylight. This is most likely true due to the fact that there are more cross-country buses and transit buses in operation during daylight conditions.

Interestingly, the number of cross-country buses involved in accidents during dark conditions is the same, whether streetlights were operational or not. However, the number of transit buses involved in accidents during dark conditions with streetlights operational is significantly higher than those during dark conditions with no streetlights.

Table 7

Distributions for Involved Cross-Country and Transit Buses by Light Conditions

\begin{tabular}{|l|c|c|c|c|}
\hline \multicolumn{1}{|c|}{ Light Conditions } & Cross-Country Buses & \% Distribution & Transit Buses & \% Distribution \\
\hline Daylight & 32 & 62.7 & 668 & 87.0 \\
\hline Dawn & 1 & 2.0 & 13 & 1.7 \\
\hline Dusk & 1 & 2.0 & 12 & 1.6 \\
\hline Dark - streetlights on & 8 & 15.7 & 58 & 7.6 \\
\hline Dark - no streetlights & 8 & 15.7 & 15 & 2.0 \\
\hline n/a & 1 & 2.0 & 2 & 0.3 \\
\hline Total & 51 & 100.0 & 768 & 100.0 \\
\hline
\end{tabular}




\section{Bus Accident Involvement by Weather Conditions}

The frequency distribution for the weather conditions that existed at the time most cross-country and transit buses were involved in accidents is contained in Table 8. The vast majority of both cross-country buses and transit buses involved in accidents were noted on clear days or days of no adverse weather conditions (70.6 percent - cross-country bus, 82.0 percent - transit bus). Of the cross-country buses involved in accidents, 15.7 percent and 3.9 percent were involved in accidents on rainy days or in sleet conditions, respectively. Of the transit buses involved in accidents, 8.7 percent and 4.0 percent of the accidents occurred on rainy days or snowy days, respectively.

Table 8

Distributions for Involved Cross-Country and Transit Buses by Weather Conditions

\begin{tabular}{|l|c|c|c|c|}
\hline \multicolumn{1}{|c|}{ Weather Conditions } & $\begin{array}{c}\text { Cross-Country } \\
\text { Buses }\end{array}$ & \% Distribution & Transit Buses & \% Distribution \\
\hline No adverse conditions & 36 & 70.6 & 629 & 82.0 \\
\hline Rain & 8 & 15.7 & 67 & 8.7 \\
\hline Sleet & 2 & 3.9 & 10 & 1.3 \\
\hline Snow & 0 & 0.0 & 31 & 4.0 \\
\hline Fog & 0 & 0.0 & 5 & 0.7 \\
\hline Smoke & 0 & 0.0 & 0 & 0.0 \\
\hline Strong Winds & 0 & 0.0 & 9 & 1.2 \\
\hline Blowing dust, sand, etc. & 0 & 0.0 & 0 & 0.0 \\
\hline Freezing rain & 1 & 2.0 & 5 & 0.7 \\
\hline Rain \& fog & 1 & 2.0 & 1 & 0.1 \\
\hline Rain \& wind & 0 & 0.0 & 3 & 0.4 \\
\hline Sleet \& fog & 0 & 0.0 & 0 & 0.0 \\
\hline Snow \& winds & 1 & 2.0 & 2 & 0.3 \\
\hline Other & 1 & 2.0 & 2 & 0.3 \\
\hline n/a & 1 & 2.0 & 4 & 0.5 \\
\hline Total & 51 & 100.0 & 768 & 100.0 \\
\hline
\end{tabular}


Bus Accident Involvement by On-Road Surface Condition

In Table 9, the frequency distribution for the conditions of the roadway(s) on which cross-country buses and transit buses were involved in accidents from 1991 through 2000 is shown. For the most part, most cross-country buses and transit buses were involved in accidents when roadway conditions are dry (70.6 percent of cross-country buses and 75.8 percent of transit buses). The next most common condition in which cross-country buses and transit buses experienced accidents is wet roadways, as 19.6 percent of cross-country buses and 14.2 percent of transit buses were involved in accidents in this condition. Ice or snow-packed roadway conditions accounted for the next greatest number of cross-country and transit buses involved in accidents with 7.8 percent and 5.3 percent, respectively.

Table 9

Distributions for Involved Cross-Country and Transit Buses By On-Road Surface Condition

\begin{tabular}{|l|c|c|c|c|}
\hline Roadway Condition & Cross-Country Buses & \% Distribution & Transit Buses & \% Distribution \\
\hline Dry & 36 & 70.6 & 582 & 75.8 \\
\hline Wet & 10 & 19.6 & 109 & 14.2 \\
\hline Snow or slush & 1 & 2.0 & 34 & 4.4 \\
\hline Ice or snow-packed & 4 & 7.8 & 41 & 5.3 \\
\hline Mud, dirt, or sand & 0 & 0.0 & 0 & 0.0 \\
\hline Debris (oil, etc.) & 0 & 0.0 & 0 & 0.0 \\
\hline Other & 0 & 0.0 & 1 & 0.1 \\
\hline n/a & 0 & 0.0 & 1 & 0.1 \\
\hline Total & 51 & 100.0 & 768 & 100.0 \\
\hline
\end{tabular}

Bus Accident Involvement by Type of Involvement

The frequency distribution for the types of involvement related to cross-country and transit buses involved in accidents from 1991 through 2000 is presented in 
Table 10. As evidenced in the table, most cross-country buses and transit buses experienced accidents that involved other motor vehicles (62.7 percent and 87.0 percent, respectively). The next greatest percent of cross-country buses in accidents involved animals (11.8 percent). Besides involvement with other moving motor vehicles, transit buses most often experienced accidents involving other parked motor vehicles (7.6 percent).

Table 10

Distributions for Involved Cross-Country and Transit Buses by Type of Involvement

\begin{tabular}{|l|c|c|c|c|}
\hline \multicolumn{1}{|l|}{ Type of Involvement } & $\begin{array}{c}\text { Cross-Country } \\
\text { Buses }\end{array}$ & \% Distribution & Transit Buses & \% Distribution \\
\hline Other non-collision & 5 & 9.8 & 15 & 2.0 \\
\hline Overturned & 1 & 2.0 & 3 & 0.4 \\
\hline Collision with... & 0 & 0.0 & 10 & 1.3 \\
\hline Pedestrian & 32 & 62.7 & 630 & 82.0 \\
\hline Other motor vehicle & 2 & 3.9 & 58 & 7.6 \\
\hline Parked motor vehicle & 1 & 2.0 & 5 & 0.7 \\
\hline Pedalcycle & 6 & 11.8 & 10 & 1.3 \\
\hline Animal & 3 & 5.9 & 30 & 3.9 \\
\hline Fixed object & 1 & 2.0 & 6 & 0.8 \\
\hline Other object & 0 & 0.0 & 1 & 0.1 \\
\hline Other & 51 & 100.0 & 768 & 100.0 \\
\hline Total & & & & \\
\hline
\end{tabular}

Bus Accident Involvement by Impact Dynamics

The frequency distribution for the particular dynamics of the impacts of accidents involving cross-country and transit buses from 1991 through 2000 is presented in Table 11. The impact dynamics criteria only apply to occurrences where the cross-country or transit bus had a collision with another moving motor vehicle. As illustrated in Table 10 previously, the number of cross-country buses and 
transit buses engaged in accidents involving other moving motor vehicles is 32 and 630, respectively. The data in Table 11 indicate that most cross-country and transit buses were involved in collisions related to rear-end or angle impact dynamics. More than 23 percent of cross-country buses were involved in accidents related to angle movement. Nearly 20 percent were involved in accidents with rear-end impacts. Thirty-six percent of transit buses were involved in accidents related to angle movement; while, 29 percent were involved in accidents with rear-end impacts.

Table 11

Distributions for Involved Cross-Country and Transit Buses by Impact Dynamics

\begin{tabular}{|l|c|c|c|c|}
\hline \multicolumn{1}{|c|}{ Impact Dynamics } & Cross-Country Buses & \% Distribution & Transit Buses & \% Distribution \\
\hline Head on & 1 & 2.0 & 10 & 1.3 \\
\hline Rear end & 10 & 19.6 & 223 & 29.0 \\
\hline Angle & 12 & 23.5 & 278 & 36.2 \\
\hline Sideswipe - opposing & 2 & 3.9 & 17 & 2.2 \\
\hline Sideswipe - overtaking & 6 & 11.8 & 69 & 9.0 \\
\hline Backed into & 0 & 0.0 & 21 & 2.7 \\
\hline Other & 1 & 2.0 & 4 & 0.5 \\
\hline n/a & 0 & 0.0 & 8 & 1.0 \\
\hline Total & 32 & 100.0 & 630 & 100.0 \\
\hline
\end{tabular}




\section{Summary of Kansas Case Study Findings}

A review of the frequency distributions for selected characteristics from Kansas' 1991 through 2000 accident database determined that a "typical" accident involving a cross-country bus during this particular time period occurred:

- on a Friday;

- during the hour of 5:00-5:59 p.m.;

- under clear weather conditions;

- on dry roadways;

- in connection with another moving motor vehicle; and

- involving a rear-end or angle impact.

A "typical" accident involving a transit bus from 1991 through 2000, according to the database, occurred:

- on a Tuesday;

- between the hours of 3:00-4:59 p.m.;

- under clear weather conditions;

- on dry roadways;

- in connection with another moving motor vehicle; and

- involving a rear-end or angle impact.

The data presented in Kansas' automated state accident database provide a good overview of the factors related to accidents involving public transit buses and private carrier buses. While the data do not reveal any significant unexpected issues or causal factors related to accidents involving cross-country buses or transit buses, the database contained data for several years affording the user greater opportunity to determine trends and identify issues, if they were to exist. 
Most factors of an accident were included in Kansas' accident database; however, an expansion of the information collected might include additional occurrence factors such as posted roadway speed and number of lanes. Inclusion of significant base data, such as number of vehicles in operation, might also provide useful information for comparison analyses.

For the most part, the method by which the Kansas Department of Transportation collects and tracks accident data, while somewhat cumbersome, affords significant detail regarding the nature and scope of bus collisions in both the public transit and private carrier industries. On very few occasions, the database included "not applicable" or "n/a" entries for various measures or conditions. In these cases, presumably, the accident reports did not include all relevant information related to the vehicles that were involved in the accidents. Ideally, Kansas should ensure that those who prepare the accident reports minimize incidences of incomplete data. Overall, however, the State of Kansas should be commended for maintaining for over a decade an accident database that includes nearly 100 percent of the reported traffic accidents in the state during that period.

\section{Case Study 2: State of Arizona}

The State of Arizona statutes affirm that law enforcement officers or public employees who investigate a motor vehicle accident resulting in bodily injury, death, or damage to the property of any person in excess of one thousand dollars or the issuance of a citation shall complete a written report of the accident. The report, according to statutes must be completed at the time of and at the scene of the accident or after the accident, and should include interviews of participants or witnesses. Further the report must be submitted within twentyfour hours after completing the investigation. 
The accident reports must also include the following information:

- the time, day, month, and year of the accident;

- location of the accident;

- identification information for all involved parties and witnesses, including name, age, sex, address, telephone number, vehicle ownership and registration and proof of insurance;

- a narrative description of the facts of the accident;

- a simple diagram of the scene of the accident; and

- the investigating officer's name, agency, and identification number.

The accident reports are submitted to the Arizona Department of Transportation (Arizona DOT) Traffic Records Section. The Arizona DOT Traffic Records Section enters data from the accident reports into a uniform statewide database, performs analysis of crash statistics, and publishes an annual summary of accident statistics. After verifying the validity of the CUTR study, Arizona DOT provided CUTR with a copy of the database on CD.

The Arizona accident records were sent in a series of large, comma-delimited text files. To facilitate analysis of the information, the data files were brought into Microsoft Access. The accident records contained in Arizona's database span from January 1991 through March 2001, and, similar to Kansas' database, included a host of descriptive accident variables such as date, time of day, the type(s) of vehicle(s) involved, light conditions, weather conditions, roadway surface condition, type of involvement, and the related impact dynamics, among others. Again, the large size of the database necessitated the use of Access to conduct frequency and cross-tabulation analyses on the data.

There were 1,098,672 reported accidents in Arizona from 1991 through 2000. However, only 44 percent of those accidents were entered into the statewide 
accident database. Table 12 shows a comparison of both the number of total accidents and the number of accidents reported in the database.

Table 12

Comparison of State of Arizona Total Accidents and Accidents Reported in Database by Year of Occurrence, 1991-2001*

\begin{tabular}{|c|c|c|c|}
\hline Year & Total Accidents & \# of Accidents in Database & $\begin{array}{c}\text { \% of Total Accidents } \\
\text { in Database }\end{array}$ \\
\hline 1991 & 85,728 & 34,209 & 39.9 \\
\hline 1992 & 89,862 & 36,251 & 40.3 \\
\hline 1993 & 97,903 & $39,7+02$ & 40.6 \\
\hline 1994 & 106,728 & 45,898 & 43.0 \\
\hline 1995 & 113,888 & 48,776 & 42.8 \\
\hline 1996 & 112,964 & 49,554 & 43.9 \\
\hline 1997 & 114,174 & 50,230 & 44.0 \\
\hline 1998 & 120,293 & 52,991 & 44.1 \\
\hline 1999 & 125,764 & 56,147 & 44.6 \\
\hline 2000 & 131,368 & 58,315 & 44.4 \\
\hline $2001^{*}$ & $n / a$ & 13,813 & $n / a$ \\
\hline Total (1991-2000) & $1,098,672$ & 485,886 & 44.2 \\
\hline
\end{tabular}

${ }^{*}$ Partial Year

The total database includes records for 485,886 accidents that involved a total of 977,048 vehicles from January 1991 through March 2001. Table 13 presents the distributions for the database-recorded accidents and vehicles by year of occurrence. As in the Kansas database, a variable was included in the Arizona database that classifies all of the involved vehicles by specific body style. The distribution of all involved vehicles by respective body style is shown in Table 14 . 
Table 13

Distributions for Accidents and Vehicles by Year of Occurrence

\begin{tabular}{|c|c|c|c|c|}
\hline Year & No. of Accidents & \% Distribution & No. of Vehicles & \% Distribution \\
\hline 1991 & 34,209 & 7.0 & 67,002 & 6.9 \\
\hline 1992 & 36,251 & 7.5 & 71,685 & 7.3 \\
\hline 1993 & 39,702 & 8.2 & 79,073 & 8.1 \\
\hline 1994 & 45,898 & 9.4 & 91,668 & 9.4 \\
\hline 1995 & 48,776 & 10.0 & 98,377 & 10.1 \\
\hline 1996 & 49,554 & 10.2 & 100,205 & 10.3 \\
\hline 1997 & 50,230 & 10.3 & 101,415 & 10.4 \\
\hline 1998 & 52,991 & 10.9 & 107,520 & 11.0 \\
\hline 1999 & 56,147 & 11.6 & 113,936 & 11.7 \\
\hline 2000 & 58,315 & 12.0 & 118,079 & 12.1 \\
\hline $2001^{*}$ & 13,813 & 2.8 & 28,088 & 2.9 \\
\hline Total & $\mathbf{4 8 5 , 8 8 6}$ & $\mathbf{1 0 0 . 0}$ & $\mathbf{9 7 7 , 0 4 8}$ & $\mathbf{1 0 0 . 0}$ \\
\hline
\end{tabular}

*Partial year only. 
Table 14

Distribution of All Involved Vehicles by Vehicle Body Style

\begin{tabular}{|c|c|c|}
\hline Code - Vehicle Body Style & $\begin{array}{c}\text { No. of } \\
\text { Vehicles }\end{array}$ & $\%$ Distribution \\
\hline 0 - Not reported & 5,787 & 0.6 \\
\hline 1 - Passenger car, regular & 373,055 & 38.2 \\
\hline 2 - Passenger car, medium & 55 & 0.0 \\
\hline 3 - Passenger car, small & 86 & 0.0 \\
\hline 4 - Pickup truck (including panel $\&$ minibus) & 561,646 & 57.5 \\
\hline 5 - Pickup truck with camper & 2,155 & 0.2 \\
\hline 6 - Other vehicle with camper & 18 & 0.0 \\
\hline 7 - Truck tractor and semi-trailer & 6,799 & 7.0 \\
\hline 8 - Truck tractor only & 209 & 0.0 \\
\hline 9 - Farm tractor or other farm vehicle & 136 & 0.0 \\
\hline $10-$ Taxicab & 1,332 & 0.1 \\
\hline 11 - Commercial bus & 5,050 & 0.5 \\
\hline 12 - Non-commercial bus & 789 & 0.1 \\
\hline 13 - School bus, type 1 & 2,832 & 0.3 \\
\hline 14 - School bus, type 2 & 377 & 0.0 \\
\hline 15 - Motorcycle (two or three wheel) & 3,493 & 0.4 \\
\hline 16 - Motor scooter or motor bicycle & 22 & 0.0 \\
\hline 17 - RV (all wheel drive, dune buggy, jalopy, custom made) & 5,937 & 0.6 \\
\hline 18 - Motor home or house car & 833 & 0.1 \\
\hline 19 - Military & 4 & 0.0 \\
\hline 20 - Special controls & 37 & 0.0 \\
\hline 21 - Emergency vehicle & 294 & 0.0 \\
\hline 22 - Other truck combination & 5,708 & 0.6 \\
\hline 23 - Other vehicle & 378 & 0.0 \\
\hline $24-$ Moped & 16 & 0.0 \\
\hline Total & 977,048 & 100.0 \\
\hline
\end{tabular}


As shown in Table 14, there were a total of 5,050 commercial buses (Body Style 11) involved in accidents during the more than 10-year period represented in the database. Commercial buses include all those other than school buses such as city transit vehicles, over-the-road coaches used by commercial bus lines, and bus vehicles utilized by tour/charter group operators.

The table also shows that 789 non-commercial buses (Body Style 12) were involved in accidents during the same period. According to staff at the Arizona DOT, non-commercial buses include all buses that are privately owned for personal conveyance purposes (e.g., buses that have been converted in mobile homes); therefore, they are not included in these analyses. The following sections detail the findings from the commercial bus-specific analysis for selected accident variables from the database.

\section{Bus Accident Involvement by Year}

Table 15 illustrates the frequency distribution by year of commercial buses involved in accidents. As the table shows, the number of commercial buses involved in accidents steadily increased from 1991 to 1996, but has fluctuated since 1996. The greatest number of commercial buses involved in accidents (632) occurred in 2000. 
Table 15

Distributions for Involved Commercial Buses by Year

\begin{tabular}{|c|c|c|}
\hline Year & Commercial Buses & \% Distribution \\
\hline 1991 & 351 & 7.0 \\
\hline 1992 & 373 & 7.4 \\
\hline 1993 & 483 & 9.6 \\
\hline 1994 & 493 & 9.8 \\
\hline 1995 & 534 & 10.6 \\
\hline 1996 & 531 & 10.5 \\
\hline 1997 & 506 & 10.0 \\
\hline 1998 & 515 & 10.2 \\
\hline 1999 & 483 & 9.6 \\
\hline 2000 & 632 & 12.5 \\
\hline $2001^{*}$ & 149 & 3.0 \\
\hline Total & $\mathbf{5 , 0 5 0}$ & $\mathbf{1 0 0 . 0}$ \\
\hline Partatyear & & \\
\hline
\end{tabular}

*Partial year only.

\section{Bus Accident Involvement by Time of Day}

Table 16 presents the frequency distribution for the various times of the day during which commercial buses were involved in accidents from 1991 through 2001. The time period during which the most commercial buses were involved in accidents is $4: 00-4: 59$ p.m. (10.0 percent). One-third of the total commercial buses in question were involved in accidents during the typical morning and afternoon peak periods (i.e., 6:00-9:00 a.m. and 3:00-6:00 p.m.). 
Table 16

Distributions for Involved Commercial Buses by Time of Day

\begin{tabular}{|c|c|c|}
\hline Time of Day & Commercial Buses & $\%$ Distribution \\
\hline 12 to $12: 59 \mathrm{AM}$ & 16 & 0.3 \\
\hline 1 to $1: 59$ AM & 10 & 0.2 \\
\hline 2 to $2: 59$ AM & 7 & 0.1 \\
\hline 3 to $3: 59$ AM & 7 & 0.1 \\
\hline 4 to $4: 59$ AM & 12 & 0.2 \\
\hline 5 to $5: 59$ AM & 62 & 1.2 \\
\hline 6 to $6: 59$ AM & 192 & 3.8 \\
\hline 7 to $7: 59$ AM & 399 & 7.9 \\
\hline 8 to $8: 59$ AM & 345 & 6.8 \\
\hline 9 to $9: 59$ AM & 252 & 5.0 \\
\hline 10 to $10: 59$ AM & 245 & 4.9 \\
\hline 11 to $11: 59$ AM & 325 & 6.4 \\
\hline 12 to $12: 59$ PM & 362 & 7.2 \\
\hline 1 to $1: 59$ PM & 347 & 6.9 \\
\hline 2 to $2: 59$ PM & 418 & 8.3 \\
\hline 3 to $3: 59$ PM & 483 & 9.6 \\
\hline 4 to $4: 59 \mathrm{PM}$ & 506 & 10.0 \\
\hline 5 to $5: 59$ PM & 435 & 8.6 \\
\hline 6 to $6: 59$ PM & 291 & 5.8 \\
\hline 7 to $7: 59$ PM & 129 & 2.6 \\
\hline 8 to $8: 59$ PM & 87 & 1.7 \\
\hline 9 to $9: 59$ PM & 51 & 1.0 \\
\hline 10 to $10: 59 \mathrm{PM}$ & 47 & 0.9 \\
\hline 11 to $11: 59$ PM & 22 & 0.4 \\
\hline Total & 5,050 & 100.0 \\
\hline
\end{tabular}

Bus Accident Involvement by Light Conditions

Table 17 shows the frequency distribution for various light conditions during which most commercial buses were involved in accidents from 1991 through 2001. The table presents the number of commercial buses involved in accidents during daylight, dawn/dusk, or dark conditions. Most of the buses were involved 
in accidents during daylight conditions. As with Kansas, this is most likely due to the increased number of buses in operation during daylight hours.

Table 17

Distributions for Involved Commercial Buses by Light Conditions

\begin{tabular}{|l|c|c|}
\hline Light Conditions & Commercial Buses & \% Distribution \\
\hline Not reported & 1 & 0.0 \\
\hline Daylight & 4,238 & 83.9 \\
\hline Dawn or dusk & 233 & 4.6 \\
\hline Darkness & 578 & 11.4 \\
\hline Total & $\mathbf{5 , 0 5 0}$ & $\mathbf{1 0 0 . 0}$ \\
\hline
\end{tabular}

Bus Accident Involvement by Weather Conditions

The frequency distribution for the weather conditions that existed at the time the buses were involved in accidents is illustrated in Table 18. The vast majority of the buses involved in accidents for which weather conditions were reported occurred on clear days. Eighty-five percent of commercial buses were involved in accidents under clear weather conditions. For commercial buses, 10.6 percent were involved in accidents on cloudy days and 3.9 percent were involved in accidents on rainy days. A very small fraction of the buses involved in accidents were reported without details regarding the weather conditions. 
Table 18

Distributions for Involved Commercial Buses by Weather Conditions

\begin{tabular}{|l|c|c|}
\hline \multicolumn{1}{|c|}{ Weather Conditions } & Commercial Buses & \% Distribution \\
\hline Not reported, no adverse conditions & 8 & 0.2 \\
\hline Clear & 4,268 & 84.5 \\
\hline Cloudy & 534 & 10.6 \\
\hline Sleet, hail & 2 & 0.0 \\
\hline Rain & 199 & 3.9 \\
\hline Snow & 20 & 0.4 \\
\hline Severe crosswinds & 10 & 0.2 \\
\hline Blowing sand, soil, dirt, snow & 6 & 0.1 \\
\hline Fog, smog, smoke & 3 & 0.0 \\
\hline Total & $\mathbf{5 , 0 5 0}$ & $\mathbf{1 0 0 . 0}$ \\
\hline
\end{tabular}

\section{Bus Accident Involvement by On-Road Surface Condition}

In Table 19, the frequency distribution for the conditions of the roadway(s) on which commercial buses were involved in accidents from 1991 through 2001 is shown. Most commercial buses (90.6 percent) were involved in accidents where road conditions were either not reported or described as not unusual. Wet roadway surface conditions seemed to pose some challenge to operators of commercial buses, as 5.3 percent of commercial buses were involved in accidents on wet roadways. The data regarding roadway conditions are not as useful as they could be if "not reported" and "no unusual conditions" were reported separately. Presumably, most of the 90.6 percent of commercial buses categorized under not reported or no unusual conditions actually were involved in accidents on roadways without unusual conditions. Unfortunately, the data do not verify that. 
Table 19

Distributions for Involved Commercial Buses by On-Road Surface Condition

\begin{tabular}{|l|c|c|}
\hline \multicolumn{1}{|c|}{ Roadway Condition } & Commercial Buses & \% Distribution \\
\hline Not reported, no unusual conditions & 4,576 & 90.6 \\
\hline Dry & 110 & 2.1 \\
\hline Wet & 267 & 5.3 \\
\hline Sand, mud, dirt, oil, or gravel & 31 & 0.6 \\
\hline Snow & 28 & 0.6 \\
\hline Slush & 1 & 0.0 \\
\hline Ice & 1 & 0.0 \\
\hline Other & 5 & 0.1 \\
\hline Unknown & 31 & 0.1 \\
\hline Total & $\mathbf{5 , 0 5 0}$ & $\mathbf{1 0 0 . 0}$ \\
\hline
\end{tabular}

\section{Bus Accident Involvement by Type of Involvement}

The frequency distribution for the type of involvement for the Arizona bus accidents is presented in Table 20. Interestingly, the Arizona DOT has classified 52 different types of possible involvements in its database, ranging from noncollision occurrences such as "fire in vehicle" and "object fall on vehicle," to various collision occurrences such as "collision with wild game" and "collision with landslide." While the level of detail this offers is appreciated, for purposes of this analysis these categories have been compressed into a smaller set of cohorts that more closely correlate to those used by the other case study states.

As illustrated in Table 20, the majority of the commercial buses involved in accidents entailed a collision with another moving motor vehicle (88.9 percent). The next highest incident type for commercial buses in accidents involved collision with some type of fixed object. 
Table 20

Distributions for Involved Commercial Buses by Type of Involvement

\begin{tabular}{|l|c|c|}
\hline \multicolumn{1}{|c|}{ Type of Involvement } & Commercial Buses & \% Distribution \\
\hline Not reported & 0 & 0.0 \\
\hline Overturning & 7 & 0.1 \\
\hline Non-collision & 32 & 0.6 \\
\hline Collision with... & \multicolumn{2}{|c|}{} \\
\hline Pedestrian & 46 & 1.3 \\
\hline Other motor vehicle & 142 & 88.9 \\
\hline Parked motor vehicle & 1 & 2.8 \\
\hline Train & 14 & 0.0 \\
\hline Animal & 99 & 0.3 \\
\hline Pedalcycle & 183 & 2.0 \\
\hline Fixed object & 17 & 3.6 \\
\hline Non-fixed object & 1 & 0.3 \\
\hline Unknown & $\mathbf{5 , 0 5 0}$ & 0.0 \\
\hline Machine transport & & 0.0 \\
\hline Total & 100.0 \\
\hline
\end{tabular}

\section{Bus Accident Involvement by Impact Dynamics}

The frequency distribution for the particular impact dynamics (referred to as "collision manner" in the Arizona accident database) of Arizona's bus accidents is presented in Table 21. Unlike the case for Kansas, where the impact dynamics applied to only those occurrences where a bus had a collision with another moving motor vehicle, the Arizona database has provided information on the manner of collision for all of its occurrences (it is presumed that the occurrences involving overturning or non-collisions are included in the "single vehicle" category). 
As illustrated in Table 21, most commercial buses were involved in impacts related to rear-end or sideswipe (on the same side) collisions. Nearly 33 percent of the commercial buses in the database were involved in a rear-end collision. The second greatest impact dynamic for commercial buses is same direction sideswipe impacts. Nearly 28 percent of commercial buses involved in accidents from 1991 through 2001 experienced sideswipe collisions with another motor vehicle traveling in the same direction.

Table 21

Distributions for Involved Commercial Buses by Impact Dynamics

\begin{tabular}{|l|c|c|}
\hline \multicolumn{1}{|c|}{ Impact Dynamics } & Commercial Buses & \% Distribution \\
\hline Not reported & 28 & 0.6 \\
\hline Single vehicle & 501 & 9.9 \\
\hline Sideswipe (same) & 1,392 & 27.6 \\
\hline Sideswipe (opposite) & 56 & 1.1 \\
\hline Angle & 869 & 17.2 \\
\hline Left turn & 206 & 4.1 \\
\hline Rear end & 1,661 & 32.9 \\
\hline Head on & 19 & 0.4 \\
\hline Backing & 110 & 2.2 \\
\hline Other & 208 & 4.1 \\
\hline Total & $\mathbf{5 , 0 5 0}$ & $\mathbf{1 0 0 . 0}$ \\
\hline
\end{tabular}




\section{Summary of Arizona Case Study Findings}

A review of the frequency distributions for selected characteristics from Arizona's accident database from 1991 through March 2001 reveals that a "typical" accident involving a commercial bus occurred:

- between the hours of 4:00-4:59 p.m.;

- under daylight conditions;

- under no adverse weather conditions;

- on a roadway with no unusual conditions;

- in connection with another moving motor vehicle; and

- involving a rear-end or same-direction sideswipe impact.

The vehicle type categories for Arizona differ greatly from those of Kansas. While the transit and cross-country buses involved in accidents are analyzed separately in Kansas, in Arizona those types of buses are categorized together under the commercial bus type. This demonstrates a significant barrier to comparing accident records by specific bus type between these states.

The database provided by the Arizona DOT was of sufficient detail to outline a similar comparison of factors related to overall bus vehicles involved in accidents with those in Kansas. Just as with the Kansas case study, the data presented did not reveal significant unexpected issues; however, it is important to note that only 44 percent of the total accidents investigated by law enforcement officials were reported to the Arizona DOT's Traffic Records Section and entered into the uniform statewide database. In addition, Arizona's accident database exhibited several instances of incomplete accident records, or those with entries of "not reported." The State of Arizona will need to address both of these types of inconsistencies to realistically identify causal factors or significant issues related to transit and cross-country bus accidents. 


\section{Case Study 3: State of Idaho}

Motor vehicle laws of Idaho state that every law officer who investigates a motor vehicle accident must send a vehicle collision report to the Office of Highway Safety at the Idaho Transportation Department (ITD) on the appropriate form approved by ITD. Police officers are required to complete a report for any motor vehicle traffic collision resulting in injury or death of any person or damage to the property of any one person to an apparent extent of $\$ 751$ or more. The collision report form, by design, is to be completed at the collision scene. It requires that the reporting officer respond to both open-ended and code-related investigative questions. The information collected on the form is verified, coded, and entered into a database at the Office of Highway Safety.

Reportable collisions occur on public roads or access roads on private property open to the public, and result in injury or damage to property of any one person to an apparent extent of $\$ 751$ or more. A report is considered valid only if a law enforcement officer has investigated the accident. Reports that have been filled out by the public, sometimes called "walk in" reports, are not considered valid because they have not been investigated.

Idaho accident data are stored in relational databases. These databases include vehicle-level information (one record for each vehicle involved in the incident) and person-level information (one record for each person involved in the incident). Thus 2,046 records were provided to relay all the information collected about the collisions. The Idaho accident records were sent to CUTR in a Microsoft Excel spreadsheet. Like the other case studies, the information was imported into Microsoft Access to facilitate data analysis. The records correspond to all of the persons that were involved in crashes that related to at least one bus of some kind (school, charter/tour, transit, etc.) in Idaho for the years from 1996 to 2000 . Like the databases for the two other case study states, the accident records contained numerous descriptive accident variables such as 
date, time of day, day of week, the type(s) of vehicle(s) involved, light conditions, weather conditions, roadway surface condition, and type of involvement, among others. Once again, Access was used to conduct frequency and cross-tabulation analyses on the data.

As noted previously, the original Idaho accident records were based on persons, rather than collisions or vehicles. As a result, the data had to be cleaned to remove duplicate vehicle records. For example, if a car carrying 3 persons rearended a bus carrying 8 persons, the database would include 11 separate records for this occurrence with identical occurrence characteristics but distinct person characteristics. After accounting for duplications, the final modified database used for this analysis includes records for 697 bus-related accidents that involved a total of 1,418 vehicles. Table 22 presents a comparison between the total traffic collisions that occurred in Idaho for each year from 1996 to 2000 and the total bus occurrences that are included in the Idaho database. According to this information, the bus-related occurrences in the database represent only 0.5 to 0.6 percent of the total collisions that have been reported in Idaho each year between 1996 and 2000.

Table 22

Comparison of State of Idaho Total Crash Data to Bus Occurrence Data, 1996-2000

\begin{tabular}{|c|c|c|c|}
\hline Year & $\begin{array}{c}\text { Total Traffic } \\
\text { Collisions in State }\end{array}$ & $\begin{array}{c}\text { Total Bus-Related } \\
\text { Occurrences in } \\
\text { Database }\end{array}$ & $\begin{array}{c}\text { \% of Total Traffic } \\
\text { Collisions }\end{array}$ \\
\hline 1996 & 23,529 & 150 & 0.6 \\
\hline 1997 & 23,839 & 128 & 0.5 \\
\hline 1998 & 24,041 & 139 & 0.6 \\
\hline 1999 & 25,076 & 153 & 0.6 \\
\hline 2000 & 26,241 & 127 & $\mathbf{0 . 6}$ \\
\hline Total & $\mathbf{1 2 2 , 7 2 6}$ & $\mathbf{6 9 7}$ & \\
\hline
\end{tabular}


In Table 23, the distributions for the Idaho bus-related accidents and vehicles by year of occurrence are shown. The Idaho database also includes a variable that classifies all of the involved "units" (i.e., person, conveyance, vehicle, etc.) by specific type. The distribution of all involved units by type is presented in Table 24.

Table 23

Distributions for Accidents and Involved Units by Year of Occurrence

\begin{tabular}{|c|c|c|c|c|}
\hline Year & No. of Accidents & \% Distribution & No. of Involved Units & \% Distribution \\
\hline 1996 & 150 & 21.5 & 301 & 21.2 \\
\hline 1997 & 128 & 18.4 & 263 & 18.5 \\
\hline 1998 & 139 & 19.9 & 281 & 19.8 \\
\hline 1999 & 153 & 22.0 & 321 & 22.6 \\
\hline 2000 & 127 & 18.2 & 252 & 17.8 \\
\hline Total & $\mathbf{6 9 7}$ & $\mathbf{1 0 0 . 0}$ & $\mathbf{1 , 4 1 8}$ & $\mathbf{1 0 0 . 0}$ \\
\hline
\end{tabular}


Table 24

Distribution of All Involved Units by Type

\begin{tabular}{|c|c|c|}
\hline Code - Unit Type & No. of Units & $\%$ Distribution \\
\hline 1 - Pedestrian & 5 & 0.4 \\
\hline 2 - Pedalcycle & 1 & 0.1 \\
\hline 3 - Motorcycle & 2 & 0.1 \\
\hline 4-Moped & 0 & 0.0 \\
\hline $5-\mathrm{ATV}$ & 0 & 0.0 \\
\hline $6-$ Car & 366 & 25.8 \\
\hline 7 - Pickup/van/panel/sport utility vehicle & 291 & 20.5 \\
\hline 8 - Pickup with camper & 8 & 0.6 \\
\hline 10 - Motor home & 1 & 0.1 \\
\hline 11 - Snowmobile & 0 & 0.0 \\
\hline $15-$ Bus & 705 & 49.7 \\
\hline 21 - Single unit truck - 2 axle/6 tires & 11 & 0.8 \\
\hline 22 - Single unit truck - 3 axle & 6 & 0.4 \\
\hline 23 - Truck with trailer & 1 & 0.1 \\
\hline 24 - Bobtail & 0 & 0.0 \\
\hline 25 - Tractor with semi-trailer & 8 & 0.6 \\
\hline 26 - Tractor with double-trailer & 4 & 0.3 \\
\hline 27 - Tractor with triple-trailer & 0 & 0.0 \\
\hline $28-$ Train & 0 & 0.0 \\
\hline 30 - Farm equipment & 4 & 0.3 \\
\hline 40 - Construction equipment & 1 & 0.1 \\
\hline 99 - Other non-motor vehicle & 0 & 0.0 \\
\hline U - Unknown/not reported & 4 & 0.3 \\
\hline Total & 1,418 & 100.0 \\
\hline
\end{tabular}


Since all of the occurrences in the Idaho database are related to accidents involving buses, it was not necessary to further pare down the database. As shown in Table 24, there were a total of 705 buses (Type 15) involved in accidents during the 5-year period represented in the database. Based on the information provided in the database, these buses were all commercial vehicles and included city transit vehicles, school buses, over-the-road coaches used by commercial bus lines, and bus vehicles utilized by tour/charter group operators. The following sections detail the findings from the bus-specific analyses for selected accident variables from the database.

\section{Bus Accident Involvement by Year}

Table 25 illustrates the frequency distribution by year of the buses involved in accidents in Idaho. As the table shows, the number of buses involved in accidents from 1996 through 2000 fluctuated and never exhibited a steady decline or increase. The year with the lowest number of buses involved in an accident (127 buses in 2000) followed the year with the greatest number of buses involved in an accident (155 buses in 1999).

Table 25

Distributions for Involved Buses by Year

\begin{tabular}{|c|c|c|}
\hline Year & No. of Buses & \% Distribution \\
\hline 1996 & 154 & 21.8 \\
\hline 1997 & 128 & 18.2 \\
\hline 1998 & 141 & 20.0 \\
\hline 1999 & 155 & 22.0 \\
\hline 2000 & 127 & 18.0 \\
\hline Total & $\mathbf{7 0 5}$ & $\mathbf{1 0 0 . 0}$ \\
\hline
\end{tabular}




\section{Bus Accident Involvement by Month}

The Idaho database includes information regarding the number of buses involved in accidents by month. Table 26 shows the frequency distribution by month for the buses involved in accidents. The two months with the greatest number of buses involved in accidents are February and December, with 94 and 95, respectively. As might be expected, June, July, and August are the months with the fewest number of buses involved in accidents, as fewer school buses operate during this time. In addition, more buses were involved in accidents during the cold weather months, which is most likely attributable to road conditions associated with the inclement weather that occurs during these months.

Table 26

Distributions for Involved Buses by Month

\begin{tabular}{|l|c|c|}
\hline Day of Week & No. of Buses & \% Distribution \\
\hline January & 86 & 12.2 \\
\hline February & 94 & 13.3 \\
\hline March & 58 & 8.2 \\
\hline April & 61 & 8.7 \\
\hline May & 51 & 7.2 \\
\hline June & 17 & 2.4 \\
\hline July & 28 & 4.0 \\
\hline August & 28 & 4.0 \\
\hline September & 61 & 8.7 \\
\hline October & 70 & 9.9 \\
\hline November & 56 & 7.9 \\
\hline December & 95 & 13.5 \\
\hline Total & $\mathbf{7 0 5}$ & $\mathbf{1 0 0 . 0}$ \\
\hline
\end{tabular}


Bus Accident Involvement by Day of Week

Table 27 shows the frequency distribution for the days of the week on which buses were involved in accidents from 1996 through 2000. The day on which most of the buses were involved in accidents is Friday. The number of buses involved in accidents on Monday, Tuesday, and Wednesday are comparable, with 135, 135, and 137, respectively. As noted in the other case studies, Saturday and Sunday are the days on which the fewest buses were involved in accidents. Again, this is most likely due to fewer transit buses and school buses operating on those days.

Table 27

Distributions for Involved Buses by Day of Week

\begin{tabular}{|l|c|c|}
\hline Day of Week & No. of Buses & \% Distribution \\
\hline Monday & 134 & 19.0 \\
\hline Tuesday & 135 & 19.1 \\
\hline Wednesday & 137 & 19.4 \\
\hline Thursday & 120 & 17.0 \\
\hline Friday & 143 & 20.3 \\
\hline Saturday & 25 & 3.5 \\
\hline Sunday & 11 & 1.6 \\
\hline Total & $\mathbf{7 0 5}$ & $\mathbf{1 0 0 . 0}$ \\
\hline
\end{tabular}

Bus Accident Involvement by Time of Day

Table 28 presents the frequency distribution for the various times of the day when the buses were involved in accidents. The time period during which most buses were involved in accidents is 3:00-3:59 p.m. (18.4 percent). Although, this does not coincide with the typical afternoon peak period of most urbanized areas 
(4:00-6:00 p.m.), the level of traffic coupled with the number of school buses on the road at that time might provide a possible explanation for this occurrence. Other times at which greater number of buses were involved in accidents are 7:00-7:59 a.m. (14.9 percent) and 8:00-8:59 a.m. (12.5 percent). Between 7:00 p.m. and 6:00 a.m., the fewest number of buses were involved in accidents. 
Table 28

Distributions for Involved Buses by Time of Day

\begin{tabular}{|c|c|c|}
\hline Time of Day & No. of Buses & $\%$ Distribution \\
\hline 12 to $12: 59 \mathrm{AM}$ & 8 & 1.1 \\
\hline 1 to $1: 59$ AM & 2 & 0.3 \\
\hline 2 to $2: 59$ AM & 2 & 0.3 \\
\hline 3 to $3: 59$ AM & 1 & 0.1 \\
\hline 4 to $4: 59$ AM & 0 & 0.0 \\
\hline 5 to $5: 59$ AM & 2 & 0.3 \\
\hline 6 to $6: 59$ AM & 11 & 1.6 \\
\hline 7 to $7: 59$ AM & 105 & 14.9 \\
\hline 8 to $8: 59$ AM & 88 & 12.5 \\
\hline 9 to $9: 59$ AM & 32 & 4.5 \\
\hline 10 to $10: 59 \mathrm{AM}$ & 22 & 3.1 \\
\hline 11 to $11: 59$ AM & 43 & 6.1 \\
\hline 12 to $12: 59 \mathrm{PM}$ & 44 & 6.2 \\
\hline 1 to $1: 59$ PM & 37 & 5.2 \\
\hline 2 to $2: 59$ PM & 68 & 9.6 \\
\hline 3 to $3: 59$ PM & 130 & 18.4 \\
\hline 4 to $4: 59$ PM & 61 & 8.7 \\
\hline 5 to $5: 59$ PM & 20 & 2.8 \\
\hline 6 to $6: 59$ PM & 14 & 2.0 \\
\hline 7 to $7: 59 \mathrm{PM}$ & 4 & 0.6 \\
\hline 8 to $8: 59$ PM & 3 & 0.4 \\
\hline 9 to $9: 59$ PM & 3 & 0.4 \\
\hline 10 to $10: 59 \mathrm{PM}$ & 3 & 0.4 \\
\hline 11 to $11: 59 \mathrm{PM}$ & 2 & 0.3 \\
\hline Total & 705 & 100.0 \\
\hline
\end{tabular}




\section{Bus Accident Involvement by Light Conditions}

Table 29 shows the frequency distribution for various light conditions during which most buses were involved in accidents from 1996 through 2000. Not all of the accident reports involving buses included light condition data; therefore, there are 701 total buses included in this distribution, rather than 705 . The table presents the number of buses involved in accidents during conditions described as: day, dawn/dusk, dark (streetlights on), dark (streetlights off), and dark (no street lights). As noted in Table 29, most buses were involved in accidents during daylight conditions (87.6 percent), the predominant condition when most transit and school buses are in operation. Buses were next most likely to be involved in an accident during dawn/dusk conditions (6 percent).

Table 29

Distributions for Involved Buses by Light Conditions

\begin{tabular}{|l|c|c|}
\hline \multicolumn{1}{|c|}{ Light Conditions } & No. of Buses & \% Distribution \\
\hline Day & 614 & 87.6 \\
\hline Dawn/dusk & 42 & 6.0 \\
\hline Dark - streetlights on & 20 & 2.9 \\
\hline Dark - streetlights off & 0 & 0.0 \\
\hline Dark - no streetlights & 25 & 3.6 \\
\hline Total & 701 & 100.0 \\
\hline
\end{tabular}

\section{Bus Accident Involvement by Weather Conditions}

The frequency distribution for the weather conditions that existed at the time the buses were involved in accidents is illustrated in Table 30. The majority of buses involved in accidents for which weather conditions were reported occurred on clear days (52.3 percent). However, nearly 34 percent of the buses were involved in accidents on cloudy days (34.6 percent). Only 8.5 percent of the 
buses were involved in accidents under snowy conditions and 2.4 percent of the buses were involved in accidents during rainy conditions. The accident report(s) for five buses involved in accidents did not include information related to weather conditions.

Table 30

Distributions for Involved Buses by Weather Conditions

\begin{tabular}{|l|c|c|}
\hline Weather Conditions & No. of Buses & \% Distribution \\
\hline Clear & 369 & 52.3 \\
\hline Cloudy & 244 & 34.6 \\
\hline Rain & 17 & 2.4 \\
\hline Snow & 60 & 8.5 \\
\hline Sleet/hail & 4 & 0.6 \\
\hline Fog & 4 & 0.6 \\
\hline Blowing dust/sand & 1 & 0.1 \\
\hline Severe crosswinds & 1 & 0.1 \\
\hline Smoke/smog & 0 & 0.0 \\
\hline Unknown/not reported & 5 & 0.7 \\
\hline Total & $\mathbf{7 0 5}$ & 100.0 \\
\hline
\end{tabular}

\section{Bus Accident Involvement by Road Surface Condition}

In Table 31, the frequency distribution for the conditions of the roadway(s) on which the buses were involved in accidents from 1996 through 2001 accidents is shown. For the most part, accidents occurred on dry-surface roadways (62.4 percent). Nearly 18 percent of the buses were involved in accidents on roadways that were icy and 10.5 percent of the buses were involved in accidents on wet roadways. Nearly nine percent of the buses were involved in accidents on roadways covered by snow. 
Table 31

Distributions for Involved Buses by Road Surface Condition

\begin{tabular}{|l|c|c|}
\hline Roadway Condition & No. of Buses & \% Distribution \\
\hline Dry & 440 & 62.4 \\
\hline Wet & 74 & 10.5 \\
\hline Slush & 7 & 1.0 \\
\hline Ice & 120 & 17.0 \\
\hline Snow & 61 & 8.7 \\
\hline Mud & 0 & 0.0 \\
\hline Water & 1 & 0.1 \\
\hline Other & 0 & 0.0 \\
\hline Unknown/not reported & 2 & 0.3 \\
\hline Total & $\mathbf{7 0 5}$ & $\mathbf{1 0 0 . 0}$ \\
\hline
\end{tabular}

\section{Bus Accident Involvement by Event Occurrence}

One major difference between the Idaho accident database and those for the other two case study states is the way that the collision records have been coded for what occurred (i.e., type of involvement) and how (impact dynamics). In the case of Idaho, a variable called "event occurrence" is used to classify each accident in terms of both "what" and "how." In addition, Idaho's accident reporting methodology calls for all events to be recorded, in order of occurrence, for each accident. Consider the example of a vehicle on a two-lane highway losing control, crossing the centerline, and running head on into an oncoming vehicle. For the other case study states, this collision would be classified for type of involvement as a collision with another motor vehicle and for impact dynamic as a head-on collision. In Idaho's database, this collision would be classified with three distinct event codes: Loss of Control (code 10), Drove L/R of Center (code 
72), and Head-on (code 50). Also, a separate "point of impact" variable would designate the collision as a head-on occurrence.

In an effort to present results that are more closely comparable with those that have been presented for the other case study states, three specific modifications have been made to the Idaho event occurrence results. First, the numerous Idaho event occurrence codes have been consolidated into fewer and more general involvement categories. For example, there are 23 different event codes to describe a single-vehicle collision with a particular fixed object. Second, two (or more) vehicle collisions that had been classified using event codes that described the impact dynamics of the event have been reclassified to describe the involvement only (i.e., collision with other motor vehicle) for purposes of detailing the various types of involvement. It is important to note, however, that the impact dynamic information was retained and analyzed for all multi-vehicle collisions so that this information could be presented, as well. Third, and finally, only the major event occurrence was selected for analysis for each of the accidents with multiple event codes. For instance, in the example noted in the previous paragraph, the head-on collision is the major occurrence, so this particular event would result in the occurrence being classified as a collision with another motor vehicle.

The following two sections illustrate the analysis results for the types of involvement and the impact dynamics of the Idaho bus-related occurrences.

\section{Type of Involvement}

As evidenced in Table 32, the majority of the buses (84.3 percent) were in accidents that involved another moving motor vehicle or multiple moving vehicles. The next highest incident type involved collision with parked motor vehicle (8.8 percent). The remaining types of involvement were rather infrequent in occurrence. The only other types of involvements to account for at least one 
percent of the buses involved in accidents were collision with unspecified fixed object ( 2.7 percent) and collision with animal (1.7 percent).

Table 32

Distributions for Involved Buses by Type of Involvement

\begin{tabular}{|l|c|c|}
\hline Type of Involvement & No. of Buses & \% Distribution \\
\hline Overturn & 6 & 0.9 \\
\hline Other non-collision & 2 & 0.3 \\
\hline Collision with... & 5 & 0.7 \\
\hline Pedestrian & 595 & 84.3 \\
\hline Other motor vehicle & 62 & 8.8 \\
\hline Parked motor vehicle & 1 & 0.1 \\
\hline Pedalcycle & 0 & 0.0 \\
\hline Train & 12 & 1.7 \\
\hline Animal & 2 & 0.3 \\
\hline Other non-fixed object & 19 & 2.7 \\
\hline Fixed object & 1 & 0.1 \\
\hline Other & $\mathbf{7 0 5}$ & 100.0 \\
\hline Total & & \\
\hline
\end{tabular}




\section{$\underline{\text { Impact Dynamics }}$}

Again, it is important to note that the frequency distribution for impact dynamics shown in Table 33 results from the analysis of the event occurrence variable in the Idaho database. As a result, and similar to the case for Kansas, the impact dynamics apply to only those occurrences where a bus had a collision with another moving motor vehicle. It also is interesting to note that Idaho's coding methodology further distinguishes head-on, rear-end, angle, and same direction occurrences by whether one of the vehicles was making a turning movement at the time of impact. The data in the table indicate that most of the buses $(36.7$ percent) were involved in rear-end impact collisions. The second most frequent dynamic of impact was angle into turning vehicle (17.0 percent).

Table 33

Distributions for Involved Buses by Impact Dynamics

\begin{tabular}{|l|c|c|}
\hline Impact Dynamics & No. of Buses & \% Distribution \\
\hline Head on & 20 & 3.4 \\
\hline Rear end & 216 & 36.3 \\
\hline Sideswiped same & 52 & 8.7 \\
\hline Sideswiped opposite & 62 & 10.4 \\
\hline Head on into turning vehicle & 14 & 2.4 \\
\hline Rear end into turning vehicle & 8 & 1.3 \\
\hline Angle & 75 & 12.6 \\
\hline Angle into turning vehicle & 101 & 17.0 \\
\hline Same direction into turning vehicle & 22 & 3.7 \\
\hline Backed into & 25 & 4.2 \\
\hline Total & $\mathbf{5 9 5}$ & $\mathbf{1 0 0 . 0}$ \\
\hline
\end{tabular}




\section{Summary of Idaho Case Study Findings}

A review of the frequency distributions for selected characteristics from Idaho's accident database from 1996 through 2000 reveals that a "typical" accident involving a bus occurred:

- during the month of December;

- on a Friday;

- between the hours of 3:00-3:59 p.m.;

- under clear weather conditions

- on a roadway with dry surface conditions

- involving a collision with another moving motor vehicle; and

- involving rear-end impact dynamics.

From the start it was more difficult to compare the impact of bus-involved accidents in Idaho with those in the other case studies because accidents are not reported by specific bus types in Idaho. For instance, of the 705 buses involved in accidents in Idaho from 1996 to 2000, it is unknown how many were transit buses. In fact, one of the initial goals of this analysis, which was to compare public transit and private carrier collisions, is not possible given the available information in the Idaho accident database. Presumably, the accident report provides the identity of the vehicle type; therefore, the database information requirements could be modified to ensure that it requests the specific types of the involved vehicles, rather than coding them so generally.

While the specificity was not utilized for this analysis, the Idaho database far exceeded the attempts of the other states in acknowledging each aspect of the accident. Database requirements to enter each collision and impact dynamic related to the accident are most useful in determining causal factors and identifying trends. 


\section{Conclusions}

Whether the ultimate goal is to compare bus accident trends within a state or between states, it appears logical that some type of uniformity in accident reporting, records collection, and database maintenance would be beneficial. Since available resources and goals and objectives may differ among states, a national process for the reporting and maintenance of accident records may not be feasible. However, CUTR's attempts at gathering somewhat similar data regarding bus accidents for each state in the country highlighted numerous instances where measures of uniformity might be implemented. These measures can generally be categorized as uniformity in accident reporting procedures and uniformity in records collection and database maintenance.

\section{Uniformity in Accident Reporting Procedures}

First and foremost, there is great difficulty in identifying the source of information regarding accident records for each state. In each state, a different entity may be responsible for collecting accident records and maintaining the accident database. While MTAP was an effective source for general contacts, it still was difficult to target the precise organization or persons responsible for the accident records collection. Even in those instances where the organization or persons were easily identifiable, encouraging their engagement in the study or even their acknowledgement of having the requested information was difficult, as is evident by the small number of case studies presented herein.

Recommendation: Establish and maintain an active list of accurate and reliable sources of accident databases for each state to ensure that information related to bus accidents or any other types of accidents are readily available to those conducting analyses. This task may be best achieved by methods similar to those used at the start of this project, which involved making contact with state officials through various resources. However, establishing such list will be a 
project in itself and will require sufficient time as potential sources of information are tracked from start to finish to ensure that they are the most reliable for obtaining the information desired. A more effective method would involve establishing a national clearinghouse to which each state could provide detailed accident data. Currently, transit organizations provide cursory accident information (generally bus involvement counts) on an annual basis through the National Transit Database (NTD), which is maintained by the Federal Transit Administration. However, due to the generality of the information included in the NTD, it does not support causal analysis. A similar organization, created to collect accident data and develop and maintain a national transit accident database, could serve as a resource to be used by those participating in the analysis of accident data.

Using the three states presented in the case studies as an example, there was little consistency in the criteria used to determine whether an accident was entered in the statewide database. Generally, states use a monetary damage threshold or an injury or fatality condition to determine if an accident report will be completed and if it will be entered into their accident database. In the case of Arizona, in order for an accident to be included in its statewide accident database, it must have resulted in at least one injury or fatality or $\$ 500$ or more in damage. Idaho state laws require accidents resulting in injury, fatality, or $\$ 751$ or more in damage to be included in the statewide accident database. In Kansas, the damage threshold is $\$ 1000$. The differences in these threshold amounts pose the obvious problem of inconsistency among eligible entries into the databases.

Recommendation: Identify a viable set of criteria, including a minimum monetary damage amount to be used by all states in determining whether or not an accident should be reported in the statewide accident database. One way of determining which criteria best serve the purpose of accident databases is to interview or survey several states to identify their reasons for establishing the 
criteria that they are currently using. In addition, the states could provide information regarding the advantages and disadvantages of their current thresholds. Steps to modify and coordinate the damage thresholds will vary depending on the existing policies of the states and the agency actually administering the database.

Another area where accident-reporting protocol could use more consistency is in the actual reporting forms. Each state develops its own accident reporting forms and protocol, which results in varied forms that could limit the ability to compare factors. In addition, incomplete reporting procedures, such as the practice of leaving sections of the form blank, reduces the opportunity of states to determine whether accident rates, causes, and trends are in line with other states.

Recommendation: Establish minimum information to be required on all accident reporting forms and ensure that each state's form is modified to reflect those standards. Also, states should encourage the reporting officers to complete all entries on the forms and refrain from leaving blank answers.

\section{Uniformity in Records Collection and Database Maintenance}

The general consensus is that the major breakdown in consistency occurs not at the accident reporting stage, but during the process of entering the data from the accident reports into the statewide databases. Besides having different criteria for determining whether an accident is placed in the statewide database, the states also select different accident characteristics to be entered into their databases. For instance, while the month in which the accident occurred was collected by Arizona, Kansas, and Idaho, only Idaho included the month as a defining characteristic in the database. In another example, the type, make, model, and year of the involved vehicles were collected on the reporting forms, but at some point during the reporting stage and database entry, involved vehicles are categorized by types and entered into the database as that type. 
The dilemma of such categorization was illustrated in the Idaho case study, in which the database lumps transit buses, school buses, and cross-country buses together. This practice prevents the analysis of causal factors and trends for specific types of buses, which was a goal of this project.

Recommendation: Similar to the accident reporting forms, certain information should be required to be entered into the database. At a minimum, states should be encouraged to separate school buses from transit and cross-country buses. Presumably, the inclusion of accidents involving school buses in Idaho's database resulted in the reduced ability to compare Idaho's accident factors with those of the Arizona and Kansas. The effects of including school buses in a general bus category are most visible in the time of day accident characteristic.

Another breakdown in the database comparison process occurs when the data are compared from year to year within the same State or when data are compared between states without the provision of some level of base data. Exposure rates, such as annual transit bus accidents to annual vehicle miles traveled by transit buses, provide more towards identifying accident trends than raw accident numbers. The inclusion of such information in the statewide databases is necessary and only enhances their usefulness.

Recommendation: Just as certain criteria related to each accident should be entered into a state's accident database, minimum base data that can be used to determine rates of exposure should also be identified in the database. Annual vehicle miles and number of operational buses are two examples of base data that could be used in this capacity.

As noted in the Idaho case study, a variable called "event occurrence" was used to classify each accident in terms of both "what" happened and "how" it happened. Since this methodology was not used by the states in the other case studies, to compare between states, a manipulation of the variables was 
required. Ideally, all of the states will choose to report types of involvement and impact dynamics in similar ways. However, what is not as clear is which way is better. In the case of Idaho, the event occurrence variable details each type of involvement of the accident, not just the one the reporting officer considers to be the major event occurrence. This presents an opportunity for all factors of the accident to be considered so that the impact of each event can be evaluated. On the other hand, in Arizona and Kansas, only the major factor in the accident is entered into the database enabling a more clear cut comparison of the causal factors of the accidents. There are benefits to each method. Clearly, the most difficult task was modifying one to be more similar to the other. If all three were presented similarly, the method selected would not be nearly as important.

Recommendation: Both the method of identifying the major type of involvement and listing all events of occurrences may have a place in the statewide accident databases. A more thorough evaluation of both methods should be conducted to determine which of the two best serves the objectives of the statewide database and analysis processes. Regardless, one method should be selected and used consistently among all states.

Mentioned previously, submitting incomplete reporting forms was a major obstacle to reliable analyses and comparisons. In turn, incomplete forms require that "not reported" entries be entered in the statewide database. In one case study, the database failed to separate "not reported" measures from, in the case of weather and roadway conditions, "no adverse conditions." Clearly, just because conditions are not available on the reporting form does not mean that the conditions were not adverse. By combining the two measures, the information in the database becomes less valuable.

Recommendation: Those who enter forms into the statewide accident database must ensure that data from incomplete accident forms are entered as such and not included with other measures that do not necessarily reflect the same 
conditions. The overall choice of database software by each state reflects their available resources, as well as their preference. While the analysis process might be improved if reporting software were identical, it is probably not likely that such compatibility will offer an immediate advantage to those maintaining the databases. The best practice, in terms of software selection, is for states to choose software that is compatible with other forms of database management software that are widely available for use.

The recommendations presented above suggest modifications to the existing statewide accident reporting and database maintenance processes. The current database maintenance processes, however, are not specific toward transit accidents and in many ways do not serve as the most appropriate resource for analysis. Another possibility regarding the tracking, reporting, and maintenance of accident records involving buses and public transit vehicles, in particular, is to develop a national accident tracking and reporting process designed to focus on accidents involving transit vehicles. Such a process would have tremendous benefit for federal, state, and local transit organizations interested in trends related to transit vehicle accidents. A national clearinghouse designed to coordinate state accident databases and disseminate data to be used in identifying trends and causal factors so that transit safety can be improved.

Clearly, the major obstacle in improving bus accident reporting and tracking is obtaining information on the state level. Some level of collaboration is needed to develop a feasible process for collecting and maintaining accident data; for without representatives on the state level making the information available, the true of value of the databases will not be met. 


\section{APPENDIX A}


Table A-1

State and Individual Contact Information

\begin{tabular}{|c|c|c|c|}
\hline State & Comments & Data Received & Reporting Procedures \\
\hline Alabama & 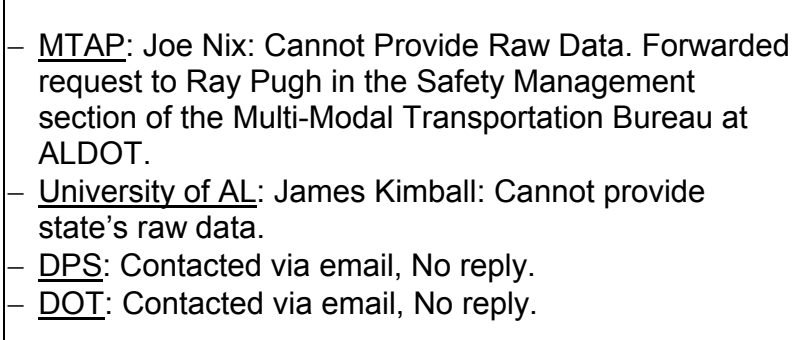 & No Data Received & $\begin{array}{l}\text { - } \frac{\text { Survey: Police fill out form for DPS for accidents }}{\$ 2000 \text { or more, or involving injury to, or death of a }} \\
\text { person. } \\
- \text { University of AL: James Kimball: Police fill out } \\
\text { standard report that is sent out to the DPS to be } \\
\text { entered into a computer system. Referred to } \\
\text { ALDOT and State Troopers. } \\
- \text { Waymon Banfield: Transit Accident Procedures } \\
\text { document (requested DOT mandated procedures). }\end{array}$ \\
\hline Alaska & $\begin{array}{l}\text { - MTAP: Bruce E. Wells: Contacted via email and fax, } \\
\text { No reply. }\end{array}$ & No Data Received & No Procedures Received \\
\hline Arizona & $\begin{array}{l}\text { - MTAP: Bill Sapper, Public Transportation Section: } \\
\text { Referred to DOT Website. } \\
\text { - DPS: Referred to DOT. } \\
\text { - AZDOT: Nancy Ann Crandall, Research and Statistical } \\
\text { Analyst: Does maintain database and will send upon } \\
\text { receiving validity of CUTR's involvement with the } \\
\text { project. }\end{array}$ & $\begin{array}{l}\text { - AZDOT: Nancy Ann Crandall, Research and } \\
\text { Statistical Analyst: CD with complete accident } \\
\text { data in text form. } \\
\text { - AZ Motor Vehicle Crash Facts } 2000 \text { report } \\
\text { containing statewide yearly trends. }\end{array}$ & $\begin{array}{l}\text { - Survey: All cities require the reporting of all } \\
\text { accidents. The state gets involved in the } \\
\text { investigation of all serious injuries and fatalities. } \\
- \text { James Gilbert: has police accident form and is } \\
\text { sending one. } \\
- \text { Nancy Crandall: traffic and vehicle definition. }\end{array}$ \\
\hline Arkansas & $\begin{array}{l}\text { - MTAP: Jim Gilbert: Individual systems may maintain } \\
\text { reports for their incidents, but are not required to file } \\
\text { them with the state. Does not maintain data containing } \\
\text { requested data. Forwarded info to Mr. Selig (Traffic } \\
\text { Safety Version). } \\
\text { - DPS: Contacted, No reply. }\end{array}$ & No Data Received & No Procedures Received \\
\hline California & $\begin{array}{l}-\frac{\text { MTAP: Contacted, No reply. }}{\text { CADOT: David Cabrera: Contacted, via email, No }} \\
\text { reply. }\end{array}$ & No Data Received & No Procedures Received \\
\hline
\end{tabular}


Table A-1

State and Individual Contact Information

\begin{tabular}{|c|c|c|c|}
\hline State & Comments & Data Received & Reporting Procedures \\
\hline Colorado & 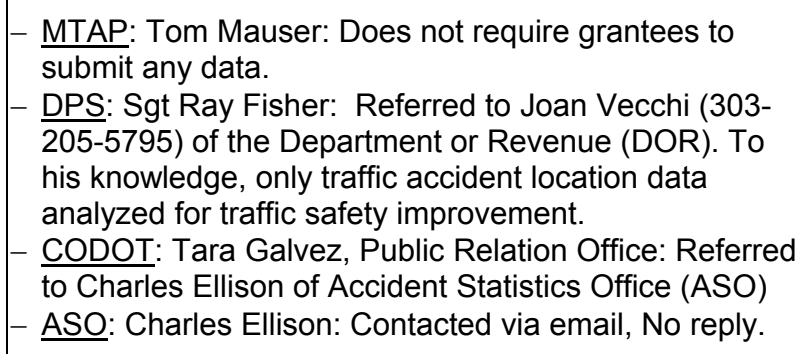 & No Data Received & $\begin{array}{l}\text { - CODOT: Tara Galvez, Public Relation Office: } \\
\text { referred to RTD-Denver website. }\end{array}$ \\
\hline Connecticut & $\begin{array}{l}\text { - MTAP: Michael Sanders: Contacted via FAX, No reply. } \\
\text { - CNDOT: Sebastian P. Puglisi, Transportation } \\
\text { Supervising Planner: Has C.A.S.T. reports for 1996- } \\
1999 \text { commercial bus data. }\end{array}$ & $\begin{array}{l}\text { - CNDOT: Sebastian P. Puglisi, Transportation } \\
\text { Supervising Planner: Connecticut Accident } \\
\text { Summary Tables for Motor Vehicle Traffic } \\
\text { Accident Data of Commercial Buses 1996- } \\
1999 \text { report. }\end{array}$ & No Procedures Received \\
\hline Florida & $\begin{array}{l}\text { - FDOT: Lula Revels: Maintains data on particular roads } \\
\text { only; does not differentiate between sections. } \\
\text { - DHSMV: Cathy English: Will provide information after } \\
\text { it's gathered. } \\
\text { - FDOT: Mr. Bailey: Contacted via FAX, No reply. } \\
\text { - } \text { FDOT: Twana Hall: Contacted via FAX, No reply. }\end{array}$ & $\begin{array}{l}\text { - FDOT: Audrey Tyner: Diskette w/ bus data } \\
\text { from 1998-2001. } \\
-\frac{\text { FDOT: Cathy English: Emails with electronic }}{\text { data. }} \\
\text { - Lynx and Hart Data from Jose Fernandez at } \\
\text { CUTR. }\end{array}$ & No Procedures Received \\
\hline Georgia & $\begin{array}{l}\text { - GODOT: Steve Kish: Charles Carr: Contacted via } \\
\text { Email and FAX, No reply. }\end{array}$ & No Data Received & $\begin{array}{l}\text { - Survey: No standard procedures, but reports } \\
\text { collected and sent to GODOT Office of Intermodal } \\
\text { Programs for evaluative purposes. }\end{array}$ \\
\hline Hawaii & - HIDOT: Julia Tsumoto: Contacted via FAX, No reply. & No Data Received & No Procedures Received \\
\hline
\end{tabular}


Table A-1

\section{State and Individual Contact Information}

\begin{tabular}{|c|c|c|c|}
\hline State & Comments & Data Received & Reporting Procedures \\
\hline Idaho & $\begin{array}{l}\text { - Susan Mulkey, ITD. Contact indicates that collision } \\
\text { report information was previously sent to Chris } \\
\text { DeAnnuntis of CUTR. } \\
\text { - Susan Mulkey: referred me to Steve Rich of ITD. }\end{array}$ & $\begin{array}{l}\text { - Steve Rich, ITD Analyst in Office of Highway } \\
\text { Safety: CD with } 5 \text { years of data in a SAS } \\
\text { database, CARS } 3.07 \text { program on floppy, } \\
\text { CARS (Crash Analysis Reporting System) } \\
\text { Users Guide, and Vehicle Collision Reporting } \\
\text { Form Manual for } 1997 . \\
\text { - Drivers License Convictions by Year Report. }\end{array}$ & $\begin{array}{l}\text { - Survey: The state requires that all collisions be } \\
\text { reported when investigated by law enforcement } \\
\text { personnel. } \\
- \text { IDDOT: Steve Rich: Sending reporting manual } \\
- \text { Janet Waver: Requires all applicants for grants to } \\
\text { include a summary of accidents for the most } \\
\text { recent year with the grant. New program to obtain } \\
\text { a list of accidents each year that we review to } \\
\text { determine collisions with FTA purchased vehicles. }\end{array}$ \\
\hline Illinois & $\begin{array}{l}\text { - ILDOT: David Spacek: Contacted via FAX, forwarded } \\
\text { request to Ed Burke. } \\
\text { - ILDOT: Ed Burke, Section } 5311 \text { Chief: Does not collect } \\
\text { data regarding any public transit bus collisions or } \\
\text { accidents. }\end{array}$ & No Data Received & No Procedures Received \\
\hline Indiana & $\begin{array}{l}- \text { INDOT: Marcy Gardner, Transit Planner: Does not } \\
\text { collect any data in requested area. For further } \\
\text { assistance contact Dale Hertwek at } 317-232-5213 . \\
- \text { Section } 16 \text { Transit Providers: } 36 \text { individual county-side } \\
\text { providers contacted. } \\
\text { - } \frac{\text { Area XI Agency on Aging (Brown County): Cheryl }}{\text { Kenyon: All property damage or injuries require a }} \\
\text { police report. Does not report incidents to DOT } \\
\text { because they are a private non-profit organization with } \\
\text { only light vehicles. } \\
- \text { Cass County Council on Aging: Contacted, No reply. } \\
- \text { Four Rivers Resource Services (Daviess County): no } \\
\text { reply } \\
- \text { Area } 12 \text { Council on Aging (Dearborn County): Julie } \\
\text { Shafer: No reply. } \\
- \text { Area } 6 \text { Community and Senior Services (Life stream } \\
\text { Services): Donna Hive: No reply. }\end{array}$ & $\begin{array}{l}\text { - INDOT: } 1999 \text { Annual Report Indiana Public } \\
\text { Transit. } \\
-\frac{\text { New Hope Services of Jeffersonville (Clark }}{\text { County): John Watkins: Reporting manual. }} \\
- \text { - Association for the Disabled of Elkhart County: } \\
\text { Judy: Faxed reporting pull-sheet form. } \\
- \text { Fayette County Council on Aging: Ruby: Faxed } \\
\text { reporting form. }\end{array}$ & $\begin{array}{l}\text { - Area IV Agency on Aging (Carroll County): Gene } \\
\text { Englekey: Does not have written procedures other } \\
\text { than writing out a police report. } \\
\text { - YMCA of Southern Indiana (Clark County): } \\
\text { Procedures outlined by insurance company and } \\
\text { cannot submit them. } \\
\text { - Clay County Council on Aging: Procedures } \\
\text { outlined by insurance company and cannot submit } \\
\text { them. } \\
\text { - DeKalb Parent's Council for Handicapped } \\
\text { Children: No written procedures available. }\end{array}$ \\
\hline lowa & $\begin{array}{l}\text { - MTAP: Contacted via Email, No reply. } \\
\text { - IADOT: Peter Hallock: Charles Carr: Contacted via } \\
\text { Email and FAX, No reply. }\end{array}$ & No Data Received & $\begin{array}{l}\text { - Survey: All collisions involving a fatality or property } \\
\text { damage must be reported. In addition, DOT's } \\
\text { Office of Public Transit requests public transit } \\
\text { systems report collisions that take a vehicle out of } \\
\text { duty for an extended period. }\end{array}$ \\
\hline
\end{tabular}


Table A-1

State and Individual Contact Information

\begin{tabular}{|c|c|c|c|}
\hline State & Comments & Data Received & Reporting Procedures \\
\hline Kansas & $\begin{array}{l}\text { - MTAP: Contacted, No reply. } \\
\text { - KSDOT: Leslie Spencer Fowler, Staff Attorney and } \\
\text { Open Records Custodian: Requires a notarized } \\
\text { document requesting data to validate CUTR's } \\
\text { involvement in the project. }\end{array}$ & $\begin{array}{l}\text { - KSDOT: Rex McCommon, Accident Data } \\
\text { Manager: Accident reporting form pull sheet. } \\
\text { - KSDOT: Rex McCommon, Accident Data } \\
\text { Manager: CD with data for 10yrs (access). } \\
\text { - KSDOT: Rex McCommon, Accident Data } \\
\text { Manager: Motor Vehicle Accident Report } \\
\text { Coding Manual (PDF). }\end{array}$ & $-\frac{\text { KSDOT: Rex McCommon: Reporting criteria on }}{\text { CD. }}$ \\
\hline Kentucky & $\begin{array}{l}\text { - KYDOT: Vickie Bourne: Does not collect } 5311 \text { data. } \\
- \text { DPS: Does not collect. Referred to Custodian of } \\
\text { Records. }\end{array}$ & No Data Received & No Procedures Received \\
\hline Louisiana & $\begin{array}{l}\text { - MTAP: Contacted, No reply. } \\
\text { - LADOT: Carol Cranshaw: MTAP: Contacted. }\end{array}$ & No Data Received & No Procedures Received \\
\hline Maine & $\begin{array}{l}\text { - MTAP: Contacted, No reply. } \\
-\frac{\text { MEDOT: Barbara Donovan: Contacted via FAX, No }}{\text { reply. }}\end{array}$ & No Data Received & No Procedures Received \\
\hline Maryland & $\begin{array}{l}\text { - MTAP: Nancy Noonan: Does not collect statewide } \\
\text { data; individual systems file reports with FTA. Provided } \\
\text { with list and street address of all urban systems in the } \\
\text { state. } \\
\text { - Urban Systems: Two out of } 27 \text { systems contacted } \\
\text { replied. } \\
\text { - Charles County Department of Community Services: } \\
\text { Lisa Quill, Chief of Housing \& Community } \\
\text { Development: Reports are reviewed at the time of the } \\
\text { incidents and evaluated for factors under their control. } \\
\text { Reports are forwarded to the insurance, and no } \\
\text { database is maintained. } \\
\text { - Garret County CAC, Inc.: Loring Young: The systems } \\
\text { is too small (20-30 vehicles) to maintain a database of } \\
\text { all accidents, most of which are fender-bender type. }\end{array}$ & No Data Received & $\begin{array}{l}\text { - Charles County Department of Community } \\
\text { Services: Lisa Quill, Chief of Housing \& } \\
\text { Community Development: Faxed report indicating } \\
\text { no minimums for reporting. }\end{array}$ \\
\hline Massachusetts & $\begin{array}{l}\text { - MTAP: Joanne Champa: Charles Carr: Contacted via } \\
\text { Email and FAX, No reply. }\end{array}$ & No Data Received & $\begin{array}{l}\text { - Survey: Require accident reports be filed by every } \\
\text { person operating a motor vehicle which is involved } \\
\text { in an accident in which any person is killed or } \\
\text { injured or in which there is a damage in excess of } \\
\text { one thousand dollars to any one vehicle or other } \\
\text { property, within five days after such accident file a }\end{array}$ \\
\hline
\end{tabular}


Table A-1

State and Individual Contact Information

\begin{tabular}{|c|c|c|c|}
\hline State & Comments & Data Received & Reporting Procedures \\
\hline & & & $\begin{array}{l}\text { report in writing to the Registrar. Any } \\
\text { investigations are subject to the jurisdiction of the } \\
\text { police department having jurisdiction on the way } \\
\text { where such accident occurred. }\end{array}$ \\
\hline Michigan & $\begin{array}{l}\text { - MTAP: Kip Grimes: Charles Carr: Contacted via Email } \\
\text { and FAX, No reply. }\end{array}$ & No Data Received & No Procedures Received \\
\hline Minnesota & $\begin{array}{l}\text { - MTAP: Donna Allan: Charles Carr: Contacted via } \\
\text { Email and FAX, No reply. }\end{array}$ & No Data Received & No Procedures Received \\
\hline Missouri & $\begin{array}{l}\text { - MTAP: Phil Richardson: Contact Passed Away. Does } \\
\text { not have data accessible through the department. } \\
\text { Request forwarded to other staff. } \\
\text { - MODOT: Contacted, No reply. }\end{array}$ & No Data Received & $\begin{array}{l}\text { - Survey: Operators must report any accident wish } \\
\text { another vehicle in which a fatality, injury, or } \\
\text { property damage in excess of } \$ 500.00 \text { occurs } \\
\text { within } 30 \text { days of such accident to the Director of } \\
\text { Revenue of the state of } \mathrm{MO} \text {. } \\
\text { - Shirley Tarwater: No written procedure. Only } \\
\text { verbal instructions when accidents occur. }\end{array}$ \\
\hline Nebraska & - $\frac{\text { MTAP: Jerry Wray: Contacted via Email and FAX, No }}{\text { reply. }}$ & - DOT Website: 1999 Crash totals. & $\begin{array}{l}\text { - Survey: Motor vehicles involved in an accident } \\
\text { resulting in property damage of } \$ 500.00 \text { or more or } \\
\text { bodily injury must be reported to the Highway } \\
\text { Safety Section in the Traffic Engineering Division } \\
\text { of the Nebraska Department of Roads. }\end{array}$ \\
\hline Nevada & $\begin{array}{l}\text { - MTAP: Tom Fronapfel: Contacted via Email and FAX, } \\
\text { No reply. }\end{array}$ & No Data Received & $\begin{array}{l}\text { - Survey: Every person operating a vehicle used by } \\
\text { any motor carrier under the jurisdiction of the TSA } \\
\text { must report each accident occurring on public }\end{array}$ \\
\hline
\end{tabular}


Table A-1

State and Individual Contact Information

\begin{tabular}{|c|c|c|c|}
\hline State & Comments & Data Received & Reporting Procedures \\
\hline & & & $\begin{array}{l}\text { highway, where a vehicle maybe have injured the } \\
\text { person or property of some person other than the } \\
\text { person or property carried by the vehicle, to the } \\
\text { sheriff or other peace officer of the county where } \\
\text { the accident occurred. If the accident immediately } \\
\text { or proximately causes death, the person in charge } \\
\text { of the vehicle, or any officer investigating the } \\
\text { accident, shall furnish to the authority such } \\
\text { detailed report thereof as required by the authority. } \\
\text { In addition, the Office of Motor Safety reviews all } \\
\text { accidents and issues a report detailing the cause } \\
\text { of the accident and the extent of injury to the } \\
\text { parties involved. }\end{array}$ \\
\hline $\begin{array}{c}\text { New } \\
\text { Hampshire }\end{array}$ & $\begin{array}{l}\text { - MTAP: Christopher Morgan: Contacted via Email, No } \\
\text { reply. } \\
\text { - NHDOT: Cathy Carrier, Project Coordinator: Contract } \\
\text { requires agencies to report accidents but no database } \\
\text { maintained due to small amount. Provided a list of the } \\
\text { seven } 5311 \text { grantees for fixed route operation. } \\
\text { - Advance Transit: Bill Schweinler, Operations Manager: } \\
\text { Report on a six month basis, do not maintain } \\
\text { database. Report to insurance company. } \\
\text { - Do not collect statewide data. }\end{array}$ & No Data Received & $\begin{array}{l}\text { NHDOT: Ms. K. Hazeltine: no written protocols. } \\
\text { Require grantees to notify the department of } \\
\text { accidents to ensure vehicles are inspected and } \\
\text { repaired. }\end{array}$ \\
\hline New Jersey & $\begin{array}{l}\text { - MTAP: Mike Silverstrov: Christopher Morgan: } \\
\text { Contacted via Email and FAX, No reply. } \\
\text { - NJDOT: Contacted, No reply. }\end{array}$ & No Data Received & $\begin{array}{l}\text { Survey: There are reporting and investigation } \\
\text { requirements associated with bus accidents and } \\
\text { incidents, such as grade crossing accidents, } \\
\text { overturned buses, runaway busses, and } \\
\text { fatal/serious injury accidents. NJDOT conducts } \\
\text { these investigations. The police may also conduct } \\
\text { investigation for violations of the motor vehicle or } \\
\text { criminal codes. }\end{array}$ \\
\hline New Mexico & $\begin{array}{l}\text { - MTAP: Josette Lucero: Christopher Morgan: } \\
\text { Contacted via Email and FAX, No reply. }\end{array}$ & No Data Received & $\begin{array}{l}\text { - Survey: MOA requires all sub grantees to report all } \\
\text { accidents to PTPB. }\end{array}$ \\
\hline
\end{tabular}


Table A-1

State and Individual Contact Information

\begin{tabular}{|c|c|c|c|}
\hline State & Comments & Data Received & Reporting Procedures \\
\hline New York & $\begin{array}{l}\text { - MTAP: Jan Simpson: Do not collect. Contact NY } \\
\text { Public Transportation Safety Board or John Fabian of } \\
\text { the PTSB. } \\
\text { - NYDOT: Contacted, No reply. }\end{array}$ & No Data Received & $\begin{array}{l}\text { - Survey: All PTSB properties are required to report } \\
\text { to PTSB staff any fatality or injury resulting from an } \\
\text { accident involving a motor vehicle subject to DOT } \\
\text { inspection or by mechanical failure. Additionally, } \\
\text { mechanical failures, evidence of intrusion into the } \\
\text { body or a vehicle of carbon monoxide, exhaust } \\
\text { fumes emitted from such vehicle, or other noxious } \\
\text { gases or smoke, smoke (other than normal } \\
\text { exhaust) emanating from the engine or any other } \\
\text { pert of the vehicle, and presence of or emission of } \\
\text { sparks, flame or fire. }\end{array}$ \\
\hline North Carolina & $\begin{array}{l}\text { - MTAP: Robinette Fisher: Do not maintain database } \\
\text { that differentiates for transit systems. Extract data } \\
\text { from the State of North Carolina Division of Motor } \\
\text { Vehicles Accidents Database. The threshold for } \\
\text { reportable accidents is } \$ 1000 \text {. } \\
\text { - } \text { NCDOT: Contacted, No reply. } \\
\text { - UNC: Mary Tucker, MLS, Librarian, University of NC: } \\
\text { UNC not recently done studies involving bus-involved } \\
\text { crashes. Referred to TRB and APTA. }\end{array}$ & $\begin{array}{l}\text { - MTAP: Summary of Accident Data for Fiscal } \\
1999 \text { and an Accident Frequency and Accident } \\
\text { Rate list. } \\
\text { - UNC: Data Pull Sheet, Commercial Bus } \\
\text { Crashes In North Carolina 1995-1999 Report } \\
\text { and An Overview of Rural Speed Crashes in } \\
\text { NC 1994-1999 Report. }\end{array}$ & $\begin{array}{l}\text { - Survey: A database of accidents and incidents is } \\
\text { currently being institutes to collect all accident with } \\
\text { over } \$ 500.00 \text { in damages, injuries and fatalities. } \\
\text { The Public Transportation Division will collect and } \\
\text { analyze the data. Currently plans are to collect } \\
\text { data from rural vehicles only. } \\
\text { - UNC: Mary Tucker: does not work for DOT. }\end{array}$ \\
\hline North Dakota & $\begin{array}{l}\text { - MTAP: Bill Weimer: Contacted via Email and FAX, No } \\
\text { reply. } \\
- \text { NDDOT: Ann Lunde, Traffic Records Supervisor: } \\
\text { Collect some data pertaining to busses. Busses are } \\
\text { categorized into two groups: school, and bus (having } \\
\text { more than sixteen passengers). Data does not } \\
\text { differentiate between public and private busses. }\end{array}$ & $\begin{array}{l}\text { - NDDOT: Ann Lunde: A table indicating Total, } \\
\text { Fatal and Injury crashes for non-school bus } \\
\text { accidents for } 1996-2000 . \text { See Table A-2: North } \\
\text { Dakota Data Insert } \\
\text { - NDDOT: Ann Lunde: Raw data available at } \\
\text { rate of } \$ 9 / 1 \mathrm{~K} \text { records. }\end{array}$ & $\begin{array}{l}\text { - Survey: All motor vehicle accidents involving } \\
\text { personal injury or over } \$ 1,000.00 \text { in } \\
\text { vehicles/property damage must be reported. }\end{array}$ \\
\hline Ohio & $\begin{array}{l}\text { - MTAP: Pat Moore, Administrator: Keep track accidents } \\
\text { for our Section } 5311 \text { but not } 5310 \text { and are not } \\
\text { responsible for private carriers. Forwarding request to } \\
\text { other staff for more specifics. } \\
\text { - } \frac{\text { OHDOT: Brett Harris, Rural Transit Coordinator: }}{\text { Information requested not readily accessible; it is }} \\
\text { gathered and collected, but not compiled into any } \\
\text { meaningful database. Can obtain raw data only if I go }\end{array}$ & No Data Received & $\begin{array}{l}\text { - Survey: } 5311 \text { rural transit systems report the } \\
\text { number of accidents and breakdowns as part of } \\
\text { their quarterly operating reports to the state. }\end{array}$ \\
\hline
\end{tabular}


Table A-1

State and Individual Contact Information

\begin{tabular}{|c|c|c|c|}
\hline State & Comments & Data Received & Reporting Procedures \\
\hline & $\begin{array}{l}\text { there my self and photocopy it (they will not mail it } \\
\text { out). Only information stored on spreadsheets does } \\
\text { not contain accident data (contain data for } \\
\text { comparisons purposes as well as an allocation of the } \\
\text { systems annual federal and state dollars). }\end{array}$ & & \\
\hline Oklahoma & 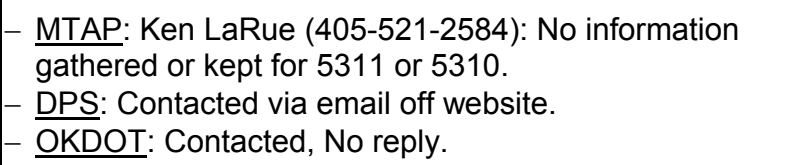 & $\begin{array}{l}\text { - OKDOT: } 1 \text { injury (side impact) } 1 \text { fatality } 3 y r s \\
\text { ago. No moving accident (this is the only data } \\
\text { available). }\end{array}$ & No Procedures Received \\
\hline Oregon & $\begin{array}{l}\text { - MTAP: Martin Loring: Contacted via Email, No reply. } \\
\text { - DPS: Office contacted does not collect any data. } \\
\text { - ORPD: Do not collect any data. Referred me to ODOT. } \\
\text { - } \text { ORPD: Lt Gary Miller, Patrol Services Division: Very } \\
\text { limited data collected because PD only responsible for } \\
\text { accidents outside of city limits and most transit } \\
\text { services are within the city boundaries. } \\
\text { - ORDOT: Sylvia M. Vogel, Crash Reporting Technician: } \\
\text { Indicates collection of data. }\end{array}$ & $\begin{array}{l}\text { - ODOT: Oregon records show they mailed out } \\
\text { on 05/24/01, but we never received. ODOT } \\
\text { Faxed the same reports on 06/21/01 upon a } \\
\text { follow-up call with the department. Data } \\
\text { showing yearly totals divided into School bus } \\
\text { and non-school bus. } \\
\text { - Website: State totals for } 1995-1999 \text {. }\end{array}$ & $\begin{array}{l}\text { - Survey: Any accident involving an injury, fatality or } \\
\text { property damage worth } \$ 1,000.00 \text { must be } \\
\text { reported to the PTD. } \\
\text { - ODOT: Kari Seely, Public Information } \\
\text { Representative: First person at the scene has the } \\
\text { responsibility of controlling the scene (removing } \\
\text { bystanders and checking upon the condition of the } \\
\text { operator). The must contact the Safety, Security } \\
\text { and operations Managers. The safety manager } \\
\text { institutes Drug and Alcohol Policies and seeks } \\
\text { medical assistance for anybody requiring } \\
\text { assistance. The operations manager contacts the } \\
\text { maintenance department to have the vehicle } \\
\text { replaced and a new vehicle delivered to the } \\
\text { appropriate location. }\end{array}$ \\
\hline Pennsylvania & 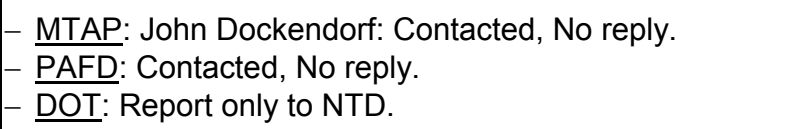 & $\begin{array}{l}\text { - Email: Explanation of various reporting } \\
\text { procedures. }\end{array}$ & - Survey: PADOT conducts the inspections. \\
\hline
\end{tabular}


Table A-1

State and Individual Contact Information

\begin{tabular}{|c|c|c|c|}
\hline State & Comments & Data Received & Reporting Procedures \\
\hline Rhode Island & $\begin{array}{l}\text { - MTAP: Contacted, No reply. } \\
\text { - RIPTA: Hadassah Moran, Planning Department: } \\
\text { Provides information to NTD only. } \\
\text { - RIPTA: Rachel Ede, Principal Planner: Collects all } \\
\text { accident information required by NTD, in addition to all } \\
\text { accidents not meeting FTA's reporting threshold for } \\
\text { severity. }\end{array}$ & No Data Received & $\begin{array}{l}\text { - RIPTA: Rachel Ede, Principal Planer: FTA does } \\
\text { not have specific procedures at this time. } \\
\text { - RIDOT: Bob Letourneau: Faxed reporting } \\
\text { procedures. Reporting goes from the Paratransit } \\
\text { Broker to the Rhode Island Public Transit Authority } \\
\text { without going through RIDOT. }\end{array}$ \\
\hline South Carolina & $\begin{array}{l}\text { - MTAP: Arlene Prince: Contacted via Email and FAX, } \\
\text { No reply. } \\
\text { - SCDOT: Marion Carman, Maintenance and Vehicle } \\
\text { Coordinator: Collects data from Public Transit and } \\
\text { Human Service providers across the state. }\end{array}$ & No Data Received & $\begin{array}{l}\text { - David Burgess: is sending reporting manual (A } \\
\text { reportable incident is one where an involved } \\
\text { vehicle sustained damages in excess of } \\
\$ 400.00) \text {. }\end{array}$ \\
\hline Tennessee & $\begin{array}{l}\text { - MTAP: Contacted, No reply. } \\
\text { - } \text { DPS: Alecia L. Craighead, Statistician: Have Crash } \\
\text { Facts reports. } \\
- \text { Transportation Department: Contacted, No reply. } \\
- \text { Commission on Aging: Contacted, No reply. } \\
- \text { General Services: Do not collect. Referred me to DPS. }\end{array}$ & $\begin{array}{l}\text { - DPS: Alecia L. Craighead: Tennessee Motor } \\
\text { Vehicle Crash Facts 1993-1997 report, Uniform } \\
\text { Crash Report Instruction Manual, and Crash } \\
\text { Report Data Pull Sheet. }\end{array}$ & No Procedures Received \\
\hline
\end{tabular}


Table A-1

State and Individual Contact Information

\begin{tabular}{|c|c|c|c|}
\hline State & Comments & Data Received & Reporting Procedures \\
\hline Texas & $\begin{array}{l}\text { - MTAP: Margot Massey: Contacted via Email, No reply. } \\
\text { - TXDOT: Ginnie Grayson, Public Information Officer: } \\
\text { Only information known is on the DPS website. } \\
\text { - DPS: Jerri Hays, Accident Records Bureau: Flat-non- } \\
\text { regional database, do not differentiate between public } \\
\text { and private, may purchase data. } \\
\text { - TXDOT: Susan Hausman, Transit System Safety } \\
\text { Manager: Do not currently maintain a database } \\
\text { covering 5310 \& } 5311 . \text { Anticipate collecting this data in } \\
\text { the future. Report only to NTD. } \\
\text { - Accident Records Bureau: Contacted, No reply. }\end{array}$ & $\begin{array}{l}\text { - DPS: Jerri Hays: Electronic Reporting Pull } \\
\text { sheet. }\end{array}$ & $\begin{array}{l}\text { - Survey: Presently, any accident is reportable to the } \\
\text { TXDOT PTD. However, a revision to the } \\
\text { Administrative Code will include the requirement to } \\
\text { report all injuries, fatalities, non-arson fires and the } \\
\text { money threshold provision of property damage } \\
\text { greater than } \$ 1,000.00 \text {. } \\
\text { - DPS: Jerri Hays, Accident Records: Texas } \\
\text { Transportation Code, Chapter } 550, \text { governs } \\
\text { reporting of accidents. } \\
\text { - TXDOT: Susan Hausman, Transit System Safety } \\
\text { Manager: Reporting is not done with any } \\
\text { consistency or uniformity. The reports go into a big } \\
\text { folder and are not entered into a database. }\end{array}$ \\
\hline Utah & 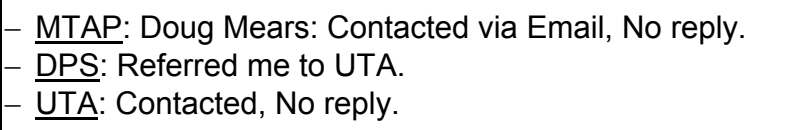 & - Website: 1999 Totals obtained. & No Procedures Received \\
\hline Virginia & $\begin{array}{l}\text { - Do not collect data at statewide level. } \\
\text { - VAPD: Contacted, No reply. }\end{array}$ & No Data Received & $\begin{array}{l}\text { - Darrell Feasel: No specific written procedures } \\
\text { regarding the process of reporting accidents, the } \\
\text { only requirement is if a vehicle has not meet FTA } \\
\text { or DRPT's useful life standards. }\end{array}$ \\
\hline Washington & - MTAP: Contacted, No reply. & No Data Received & No Procedures Received \\
\hline
\end{tabular}


Table A-1

State and Individual Contact Information

\begin{tabular}{|c|c|c|c|}
\hline State & Comments & Data Received & Reporting Procedures \\
\hline West Virginia & $\begin{array}{l}\text { - MTAP: Susan O'Connell: Have Quarterly Reports. } \\
\text { - Public Transit: Contacted, No reply. } \\
\text { - WVDOT: Request forwarded to Ray Lewis, Traffic } \\
\text { Engineering Division of theState's Accident Records } \\
\text { section. }\end{array}$ & $\begin{array}{l}\text { - MTAP: One report where no accidents } \\
\text { occurred. } \\
\text { - WVDOT Division of Public Safety: Sample } \\
\text { Accident Pull Sheets. }\end{array}$ & 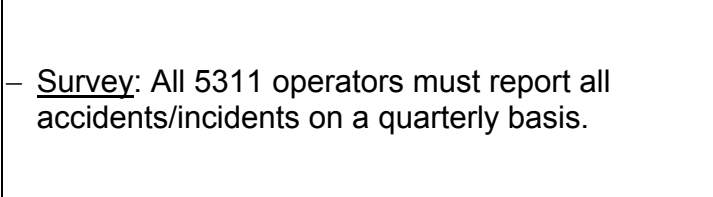 \\
\hline Wisconsin & - MTAP: Contacted, No reply & No Data Received & $\begin{array}{l}\text { - Linda Lovejoy: Referred to Richard Martin for } \\
\text { procedures. } \\
\text { - Richard Martin: There are no written procedures. }\end{array}$ \\
\hline Wyoming & - MTAP: Contacted, No reply & No Data Received & No Procedures Received \\
\hline
\end{tabular}


Table A-2

North Dakota Yearly Totals Data Insert

\begin{tabular}{|c|c|c|c|}
\hline Year & Total & Fatal & Injury \\
\hline 1996 & 49 & 1 & 10 \\
\hline 1997 & 59 & 0 & 18 \\
\hline 1998 & 29 & 0 & 4 \\
\hline 1999 & 26 & 0 & 9 \\
\hline 2000 & 37 & 1 & 11 \\
\hline
\end{tabular}

Table A-3

South Dakota Yearly Totals Data Insert

\begin{tabular}{|c|c|r|r|r|r|}
\hline Year & Type & \multicolumn{1}{|c|}{ Total } & \multicolumn{1}{c|}{ Fatality } & \multicolumn{1}{c|}{ Injury } & \multicolumn{1}{c|}{ Damage } \\
\hline \multirow{3}{*}{1996} & Bus & 85 & 1 & 18 & 66 \\
\cline { 2 - 6 } & All & 35,791 & 202 & 9,747 & 25,842 \\
\hline \multirow{3}{*}{1997} & Bus & 67 & 1 & 12 & 54 \\
\cline { 2 - 6 } & All & 33,866 & 182 & 9,281 & 24,403 \\
\hline \multirow{3}{*}{1998} & Bus & 72 & 0 & 13 & 59 \\
\cline { 2 - 6 } & All & 31,435 & 221 & 8,711 & 22,503 \\
\hline \multirow{3}{*}{1999} & Bus & 80 & 1 & 21 & 58 \\
\cline { 2 - 6 } & All & 31,795 & 200 & 8,712 & 22,883 \\
\hline \multirow{2}{*}{2000} & Bus & 71 & 0 & 20 & 51 \\
\cline { 2 - 6 } & All & 30,751 & 221 & 9,063 & 21,467 \\
\hline
\end{tabular}

